\title{
Kamu Yatırımlarının Özel Sektör Yatırımlarını Dışlama Etkisi: Türkiye Örneği
}

\section{Yenal KESBiç $\quad$ Özlem DÜNDAR ${ }^{2}$}

Ata DEVRIM ${ }^{3}$

$\ddot{O}_{z}$

Devletin ekonomik istikrar, ekonomik büyüme ve gelir dağ̆llımında adaleti sağlamak amacıyla kamu yatırım harcamaların arttırarak ekonomiye müdahale etmesi sonucuoluşan bütçe açıkların finanse etmek için vergi gelirlerinin yetersiz kalması durumunda, borçlanmaya gidilmekte, böylece kamu yatırımlarının özel sektör yatırımlarını dışlama etkisi oluşmaktadır. Türkiye'de kamu yatırımlarının özel sektör yatırımların dışlama etkisi, 1986- 2014 dönemi için Johansen eşbütünleşme testi, en küçük kareler yöntemi ve Engle Granger nedensellik testi ile analiz edilmiştir. Analiz sonuçlarına göre; kamu sabit sermaye yatırımlarının özel sektör sabit sermaye yatırımların dışladığı, kamu yatırımlarının özel sektöryatırımlarının, özel sektör yatırımlarının da kamu yatırımlarının granger nedeni olmadı̆̆g görülmüştür.

Anahtar Kelimeler: Kamu Yatırımları, Özel Sektör Yatırımları, Dışlama Etkisi, Johansen Eşbütünleşme Testi, Granger Nedensellik Testi

JEL Sinıflandırma Kodları:E00, E62, H5

\section{Crowding Out Effect of Public Investments on Private Sector Investments: The Turkey Example}

\begin{abstract}
In the event of tax revenues falling short of financing the budget deficits which occur as the result of state's intervention to economy for the purposes of economic stability, economic growth and of ensuring justice in income distribution by increasing public investment expenditures, borrowing is opted, thus crowding out effect occurs. The crowding out effect of public investments on private sector investments in Turkey, for the period of 1986-2014 is analayzed with Johansen Cointegration Test, Least Squares Method and Engle Granger Causality Test. According to the analysis results; it is observed that public fixed capital investments crowd out private sector fixed capital investments, public investments are not the granger cause of private sector investments and private sector investments are not the granger cause of public investments.
\end{abstract}

Keywords: Public Investments, Private Sector Investments, Crowding Out, Engle Granger Causality Test, Johansen Cointegration Test

JEL Classification Codes: E00,E62, H5

\footnotetext{
${ }^{1}$ Prof. Dr. Celal Bayar Üniversitesi, İktisadi ve İdari Bilimler Fakültesi, İktisat Bölümü, c.yenalkesbic@gmail

${ }^{2}$ Doktora Öğrencisi, Celal Bayar Üniversitesi, Sosyal Bilimler Enstitüsü, İktisat Ana Bilim Dalı, ozlemdundarr@gmail.com

${ }^{3}$ Doktora Öğrencisi, Celal Bayar Üniversitesi, Sosyal Bilimler Enstitüsü, İktisat Ana Bilim Dalı, atadevrim001@windowslive.com
} 


\section{Y. KESBİÇ. - Ö. DÜNDAR - A. DEVRİM}

\section{GİRIS}

Dışlama etkisi (crowding out) genel olarak genişletici maliye politikası sonucu görülen bir olgudur. Vergi ya da borçlanma yoluyla finansmanı gerçekleştirilen kamu yatırımları, ekonomi üzerinde beklenen canlanmayı yaratamadı̆̆ında, özel sektörün dişlandığı kabul edilmektedir (Carlson ve Spencer, 1975: 3). Kamu yatırımları arttığında faiz oranları artmakta, dolayısıyla sermayenin daha pahalı gelmesi sonucunda özel yatırımlar azalmaktadır. Söz konusu görüşün tam tersine, bir ekonomide kaynaklar tam olarak kullanılmadığında, kamu yatırımları özel yatırımlar üzerinde bir "çekme" etkisi (crowding in) yaratmaktadır (Ahmed ve Miller, 2000: 124-125).

Kamu yatırımlarının özel yatırımlarla olan ilişkisi çok yönlü açıklanabilmektedir. Bu ilişkiye yönelik bir açıklama, kıt kaynaklar açısından kamu sektörünün özel sektör ile rekabet halinde olduğu, dolayısıyla kısa dönemde kamu yatırımlarının özel yatırımlar üzerinde olumsuz etkisi olabileceği, kamu yatırımlarının altyapı yatırımları ile özel yatırımları desteklediği, şeklindedir. Bir başka açıklama, kamu yatırımlarının özel sektörün ürettiği mallara yönelik talebi arttırdığı yönündedir. Söz konusu ilişkiye yönelik son bir açıklama ise, kamu yatırımlarının çıktıyı ve tasarrufları arttırarak, dışlama etkisinden kaynaklanan kaybı gidereceği doğrultusundadır (Sundararajan ve Thakur, 1980: 815).

Çalışmada dışlama etkisi; öncelikle iktisadi düşünce sistemlerine göre teorik olarak genel çerçevede analiz edildikten sonra, çalışmada kullanılan değişkenlerin 1986- 2014 dönemini içeren Türkiye’ye ait verilerinin analizi gerçekleştirilmiş, izleyen aşamada konuyla ilgili yapılmış çalışmalarda kullanılan modellerin değerlendirilmesiyle ampirik olarak analiz gerçekleştirilmiş, son olarak 1986- 2014 dönemine ait verilerle, Türkiye için ekonometrik analiz yapılmıştır.

Çalışmada iktisadi düşünce sistemlerinin dışlama etkisi ile ilgili görüşlerinde, farklılık olduğu görülmüştür. Dışlama etkisine yönelik yapılmış yerli ve yabancı ampirik çalışmalarda, kamu yatırımlarının özel sektör yatırımlarına etkisine ilişkin, görüş birliği sağlanamadığı belirlenmiştir. Türkiye ile ilgili yapılan çalışmaların 
çoğunluğunda ise, kamu yatırımlarının özel sektör yatırımlarını dışladığı sonucuna ulaşı1mıştır.

Bu çalışmada, Türkiye'de kamu yatırımlarının özel sektör yatırımlarını dışlama etkisi 1986- 2014 dönemi için, Johansen eşbütünleşme testi, en küçük kareler yöntemi (EKKY) ve Engle Granger nedensellik testi ile analiz edilmiştir. Türkiye'de kamu açıklarının özellikle 1987 yılından sonra hızla büyümesi ve çalışmada kullanılan değişkenlerin tümüne ait verilerin 2015 yılına kadar elde edilmesi nedeniyle, Türkiye için 1986- 2014 dönemine ait verilerle analiz gerçekleştirilmiştir. Çalışmada GSMH değişkenine ait verilere 2006 yılından sonra ulaşılamaması nedeniyle, GSYİH verilerinden yararlanılarak, bazı değişkenlerin GSYİH’ye oranı kullanılmıştır.

\section{DIȘLAMA ETKİSININ TEORİK ANALİZi}

Dışlama etkisi; Klasik iktisat, Neo-klasik iktisat, Monetarist iktisat ve Keynesyen iktisat gibi iktisadi düşünce sistemlerine göre, söz konusu iktisadi sistemlerin önemli düşünürlerinin görüşlerine kısaca yer verilerek, teorik olarak genel çerçevede analiz edilmektedir.

Klasik İktisat düşünürlerinden Adam Smith, kamusal emeği "üretken-olmayan emek" olarak görmüş, kaynakların vergi ya da borçlanma yoluyla özel sektörden kamu sektörüne aktarılmasına karşı çıkmıştır. John Stuart Mill ve Jean Baptiste Say de özel yatırımların özel tasarrufları en iyi biçimde değerlendirdiğinden, hükümet harcamalarının ekonomik açıdan zorunluluk olmadığı görüşündedir. Özetle klasik iktisadi görüşe göre, kamu yatırımlarında meydana gelecek artış borçla veya vergilerle finanse edildiğinde mal ve hizmet talebi artmakta, böylece faiz oranlanı yükselmekte ve sermaye daha pahalı hale geleceği için özel sektör yatırımları azalmaktadir (Ahmed ve Miller, 2000: 124).

Neo-Klasik İktisatta da aynı görüş savunulmuştur. Hawtrey, kamu yatırımlarının özel yatırımların yerini alamayacağını, kamu borçlanmasının faiz oranlarını yükselterek, özel sektörün kredi kullanımını engelleyeceğini belirtmiştir. 


\section{Y. KESBİÇ. - Ö. DÜNDAR - A. DEVRİM}

Monetarist iktisada göre de, kamu yatırımları vergi ya da borçlanmayla finanse edildiğinde kaynaklar özel sektörden kamu sektörüne aktarılmakta, "dışlama etkisi” meydana gelmektedir. Monetarist iktisat, parasal genişlemenin kamu yatırımlarında artış olmaksızın ekonomiyi canlandırabileceğini savunmaktadır.

Keynesyen teoriye göre ise, vergiler ya da borçlanmayla finansmanı gerçekleştirilen kamu yatırımlarının, ekonomide genişletici etkisi bulunmaktadır. Keynes'e göre ekonomi politikasının finansman biçiminin, faiz oranlarını yükselterek yatırımlar üzerinde geciktirici bir etkisi olabilmektedir. $\mathrm{Bu}$ durumda özel yatırımcı için sermaye mallarının maliyetinin yükselmemesi için para otoritelerinin müdahalesi ile faiz oranlarının düşürülmesi gerekmektedir. Keynes, dışlama etkisi durumunda hükümet programı, yarattığı güvene karşın, likidite tercihini yükseltebilir ya da sermayenin marjinal verimliliğini azaltabilmektedir (Spencer ve Yohe, 1970: 14-7; Carlson ve Spencer, 1975: 5).

Literatürde üç çeşit dışlama etkisinden söz edilmektedir. Birincisi, kamu yatırımlarındaki artış, özel sektörün kamu mallarını özel mallarla ikame etmesine yol açmaktadır. İkincisi, çıktı miktarındaki artış para talebini ve dolayısıyla faiz oranlarını arttırarak, özel sektör yatırımlarının dışlanmasına neden olmaktadır. Üçüncüsü ise, bütçe açıkları nedeniyle kamu borç stoku faiz oranlarını arttırarak, özel sektör yatırımlarının dışlanmasına yol açmaktadır.

Friedman (1972: 917-921), birinci tür dişlama etkisini, "ilk tur" etkileri olarak isimlendirmektedir. Bunlar politikanın uygulanması ile birlikte ortaya çıkmakta ve zamana bağlı olmamaktadır. "İzleyen tur" olarak adlandırılan üçüncü tür dışlama etkisi ise, kamu borç stokunun artış hızına bağlıdır. Friedman'a göre bütçe açı̆̆ıyla finansmanı yapılan kamu yatırımları, istihdam üzerinde ilk aşamada olumlu etkide bulunabilir, ancak izleyen aşamanın faiz oranları ve yatırımlar üzerindeki etkileri, bu olumlu etkiyi ortadan kaldırmaktadır. Blinder ve Solow (1973), eğer bütçe uzun vadede ve istikrarlı olarak dengedeyse, ilk aşamada oluşan söz konusu olumlu etkilerin, tamamen dışlanmayacağını savunmaktadır (Floyd ve Hynes, 1978: 97). 
Dokuz Eylül Üniversitesi İktisadi ve İdari Bilimler Fakültesi Dergisi Cilt:31, Sayı:2, Yll:2016, ss. 59-94

\section{3. ÇALIŞMADA KULLANILAN DEĞIŞKENLERIN VERISSEL ANALIZİ}

Çalışmada özel sabit sermaye yatırımları, kamu sabit sermaye yatırımları, iç borç stoku ve iç borç faiz oranı değişkenlerine ait 1986- 2014 dönemini içeren Türkiye verileri, yıllara göre gösterdikleri değişim dikkate alınarak, analiz edilmiştir. Böylece, ilerleyen aşamalarda Türkiye için 1986- 2014 dönemi için yapılacak ampirik analizden önce, ön analiz yapılması hedeflenmiştir.

Aşağıda tablo 1'de görüldüğü üzere, özel sabit sermaye yatırımlarında yıllar itibariyle artış ve azalışlar görülmüş, söz konusu yatırımların en düşük seviyesi, 2002 ve 2003 yıllarında gerçekleşmiştir. Kamu sabit sermaye yatırımlarında da özel sabit sermaye yatırımlarında olduğu gibi artış ve azalışlar görülmüş, söz konusu yatırımların, 2008 yılı ve sonrasında neredeyse aynı oranda olduğu belirlenmiştir. Yine iç borç stokunda da, yıllara göre artış ve azalışlar görüşmüş, söz konusu değişken 2001 yılında en yüksek seviyesine ulaşmışken, 2001 yılından 2008 yılına kadar iç borç stokunda sürekli bir düşüş görülmüştür. İç borç faiz oranında da aynı şekilde, yıllara göre artış ve azalışlar gerçekleşmiştir. İç borç faizi en yüksek seviyesine 1994 yılında ulaşmış, 2009 yılından sonra da neredeyse aynı oranda seyretmiştir.

Tablo 1. Çalışmada Kullanılan Değişkenlerin Verisel Analizi

\begin{tabular}{|c|c|c|c|c|}
\hline Yıllar & $\begin{array}{c}\text { Özel } \\
\text { Sabit Sermaye } \\
\text { Yatırımları }\end{array}$ & $\begin{array}{c}\text { Kamu } \\
\text { Sabit Sermaye } \\
\text { Yatırımları }\end{array}$ & $\begin{array}{c}\text { İç Borç } \\
\text { Stoku }\end{array}$ & $\begin{array}{c}\text { İç Borç } \\
\text { Faiz Oranı }\end{array}$ \\
\hline 1986 & 9,392228 & 7,605244 & 15,31243 & 47,12 \\
\hline 1987 & 10,96226 & 7,44689 & 17,14179 & 56,6 \\
\hline 1988 & 12,82947 & 6,592042 & 16,38253 & 67,6 \\
\hline 1989 & 11,28676 & 5,676432 & 13,72279 & 59,8 \\
\hline 1990 & 11,77358 & 5,239517 & 10,82197 & 54,0 \\
\hline 1991 & 12,10946 & 5,617852 & 11,52814 & 80,5 \\
\hline 1992 & 12,05038 & 5,531194 & 13,21554 & 87,7 \\
\hline 1993 & 14,32104 & 5,404307 & 13,41334 & 87,6 \\
\hline 1994 & 14,62024 & 3,693224 & 15,37098 & 164,4 \\
\hline 1995 & 14,88932 & 3,148904 & 13,04315 & 121,9 \\
\hline
\end{tabular}




\section{Y. KESBİÇ. - Ö. DÜNDAR - A. DEVRİM}

\begin{tabular}{|c|c|c|c|c|}
\hline 1996 & 15,07952 & 3,844528 & 15,85804 & 135,2 \\
\hline 1997 & 15,33872 & 4,599029 & 16,21006 & 127,2 \\
\hline 1998 & 13,76402 & 4,785305 & 16,54183 & 122,5 \\
\hline 1999 & 11,62188 & 4,945537 & 21,91304 & 109,5 \\
\hline 2000 & 11,9837 & 5,16153 & 21,85351 & 38,0 \\
\hline 2001 & 9,229026 & 4,703962 & 50,85138 & 96,2 \\
\hline 2002 & 8,609609 & 4,938332 & 42,76174 & 63,8 \\
\hline 2003 & 8,825279 & 3,801288 & 42,74296 & 45,0 \\
\hline 2004 & 10,87677 & 3,215743 & 40,15557 & 25,7 \\
\hline 2005 & 11,25988 & 3,787504 & 37,72074 & 16,9 \\
\hline 2006 & 12,28378 & 4,009758 & 33,15837 & 18,2 \\
\hline 2007 & 17,89547 & 3,857408 & 30,27947 & 18,8 \\
\hline 2008 & 16,09963 & 4,109339 & 28,91293 & 19,3 \\
\hline 2009 & 13,10296 & 4,112361 & 34,64402 & 12,7 \\
\hline 2010 & 14,9551 & 4,277713 & 32,11152 & 8,5 \\
\hline 2011 & 18,00904 & 4,103108 & 28,41756 & 8,7 \\
\hline 2012 & 16,31883 & 4,242542 & 27,28276 & 8,8 \\
\hline 2013 & 15,59784 & 4,987296 & 25,71363 & 7,7 \\
\hline 2014 & 15,78682 & 4,878056 & 23,69718 & 9,8 \\
\hline
\end{tabular}

Çalışmada kullanılan değişkenlere ait verilerin yıllara göre değişimi, aşağıda şekillerle de gösterilmiştir. Özel sabit sermaye yatırımlarında, aşağıda Şekil 1'de görüldüğü üzere, hem artış hem de düşüşler görülmüş, söz konusu yatırımlarda en düşük seviye, 2002 ve 2003 yıllarında gerçekleşmiştir.

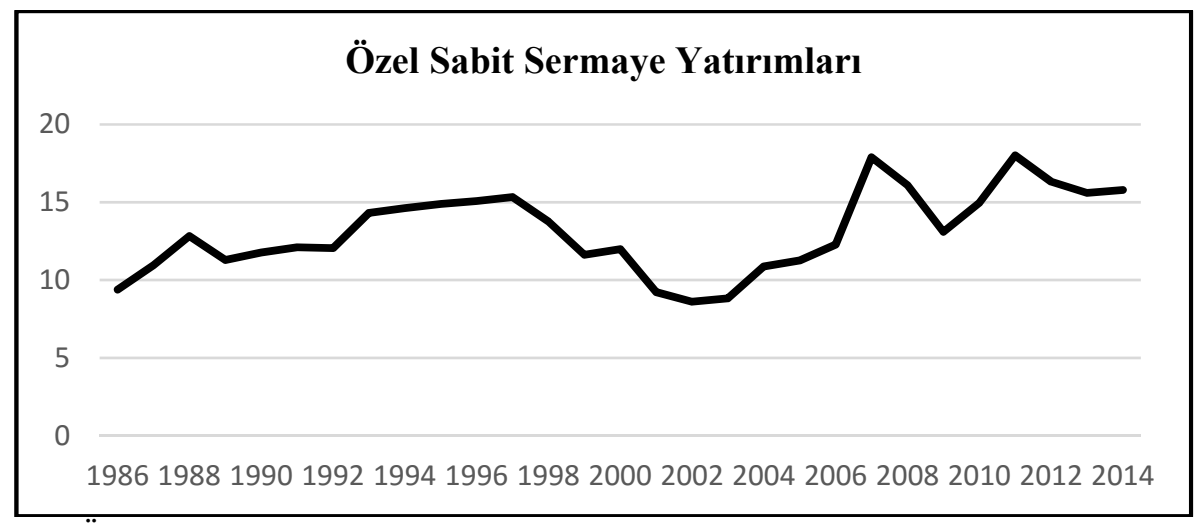

Şekil 1. Özel Sabit Sermaye Yatırımları (1986- 2014) 
Dokuz Eylül Üniversitesi İktisadi ve İdari Bilimler Fakültesi Dergisi Cilt:31, Sayı:2, Yıl:2016, ss. 59-94

Kamu sabit sermaye yatırımlarında da, özel sabit sermaye yatırımlarında olduğu gibi, aşağıda Şekil 2'de görüldüğü üzere, artış ve azalışlar görülmüştür. Özel sabit sermaye yatırımlarındaki düşüş ve artış oranlarının, kamu sabit sermaye yatırımlarındaki artış ve düşüş oranlarından daha belirgin olduğu söylenebilmektedir.

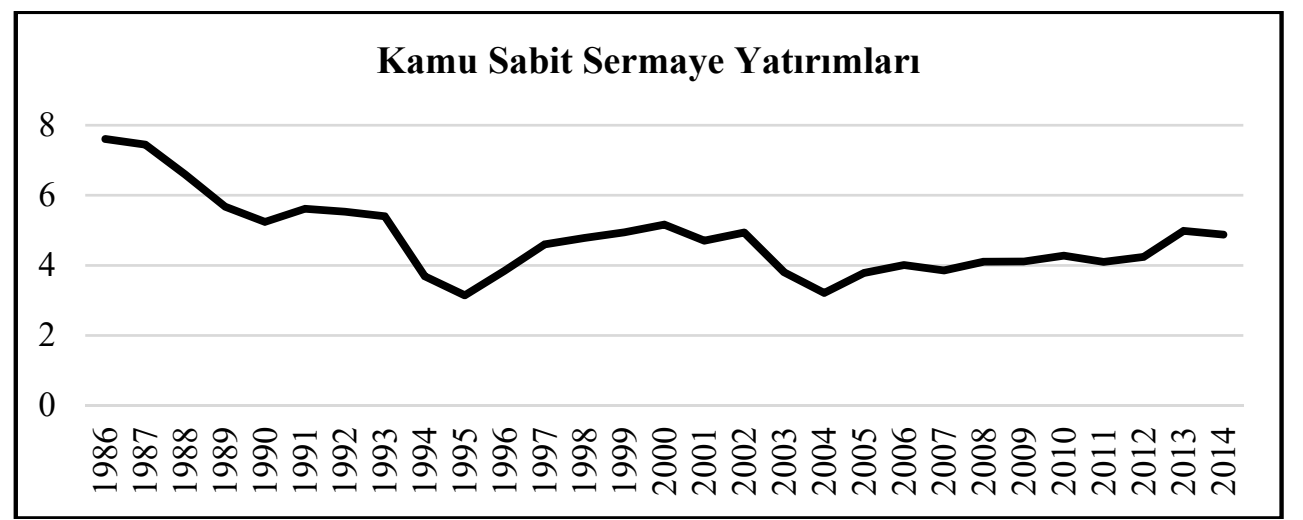

Şekil 2.Kamu Sabit Sermaye Yatırımları (1986- 2014)

İç borç stokunda, aşağıda Şekil 3'te görüldüğü üzere, 2000 y1lına kadar belirgin bir artış ya da azalış görülmemiş, 2000- 2001 yılları arasında diğer yıllara kıyasla yüksek oranda bir artış görülürken, hemen ardından 2001- 2009 yılları arasında ağırlıklı olarak azalış görülmüştür.

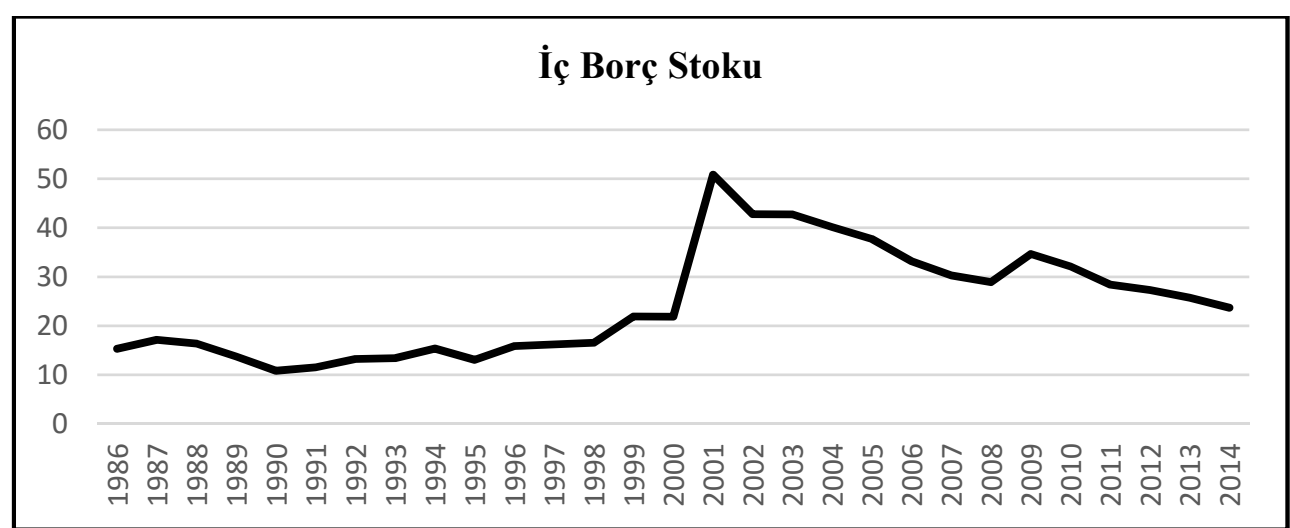

Şekil 3. İç Borç Stoku (1986- 2014)

Son olarak iç borç faiz oranının, aşağıda Şekil 4'te görüldüğüü üzere, yıllara göre atış ve azalışlar gösterdiği söylenebilmektedir. Özellikle 2009 yılı sonrasında iç 


\section{Y. KESBİÇ. - Ö. DÜNDAR - A. DEVRİM}

borç faizinde çok küçük oranda değişimler görülmesi nedeniyle, söz konusu değişken neredeyse yatay bir seyir izlemektedir.

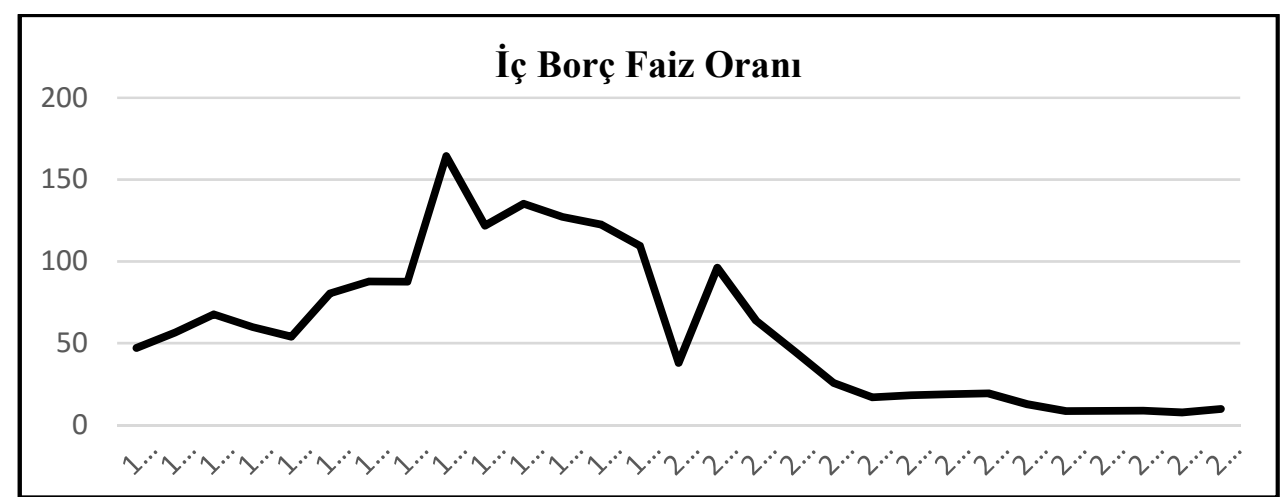

Şekil 4. İç Borç Faiz Oranı (1986- 2014)

\section{DIŞLAMA ETKİSI ILE İLGILİ AMPIRİK ÇALIŞMALARIN} ANALİí

Dışlama etkisi ile ilgili, geçmişten günümüze yapılmış yerli ve yabancı çalışmaların çoğuna bu çalışmada yer verilmeye çalışılarak, söz konusu çalışmalar, kullandıkları modeller ve bu modeller doğrultusunda ulaştıkları sonuçlar açısından analiz edilmiştir.

Blinder ve Solow (1973) çalışmalarında Monetaristlerin eleştirileri doğrultusunda Keynesyen çarpan düzeneğini yeniden ele alarak, maliye politikasının etkinliğini kanıtlamayı amaçlamışlardır. Keynes gibi, bütçe açı̆̆ı harcamalarına parasal genişleme eşlik etmediğinde faiz oranlarının yükseleceğini ve faize karşı duyarlı özel yatırımların azalacağını belirtmektedirler. Kısmi olarak gerçekleşen bu dışlama etkisi nedeniyle harcama çarpanı teorik olarak beklenenden düşük olmakta, para talebinin faize olan duyarlılığının son derece düşük olması durumunda ise, maliye politikaları etkisiz olmaktadır. Monetaristler, ampirik olarak bu durumun tersi olan kanıtları görmezden gelmekte ve maliye politikasının tamamen etkisiz olduğunu savunmaktadırlar. Ne var ki, kamu borçlanması birtakım borç araçlarının yaratılmasını gerektirmekte, bu borç araçları özel serveti arttırarak, "servet etkisi”ne yol açmaktadır. Dışlama etkisinde “üçüncü tur” ile ilgili argüman bu servet etkisi üzerinden geliştirilecektir. 
Servet etkisi, tüketimin artmasıyla toplam harcamaların artmasına yol açmakta, IS eğrisini sağa kaydırarak, bilinen çarpan etkisinin artmasını sağlamaktadır. Servetteki bu artış, finans piyasalarını etkileyerek, para talebi arttırmakta, böylece LM eğrisi de kaymaktadır. Tamamen dışlama etkisinin görüleceğini savunan Monetaristler için IS ve LM'de görülen bu kaymalar, daraltıcı bir sonuç doğurmaktadır. Blinder ve Solow, maliye politikasının sonuçlarını tartışabilmek için, aşağıdaki denklem (1) - (8)'den oluşan bir modelden yola çıkmaktadırlar:

$\begin{array}{ll}\text { (Mal piyasası dengesi) } & Y=C+I+G \\ \text { (Tüketim fonksiyonu) } & C=C(Y-T, W) \\ \text { (Net yatırım fonksiyonu) } & I=I(r) \\ \text { (Vergi fonksiyonu) } & T=T(Y) \\ \text { (Reel balans talebi) } & M_{d} / P=L(r, Y, W) \\ \text { (Egzojen para arzı) } & M_{s}=M \\ \text { (Para piyasası dengesi) } & M_{s}=M_{d} \\ \text { (Servet tanımı) } & W=K+M / P+V(r) / P\end{array}$

Yukarıda, denklem (8)'de, $V(r)$, kamu tahvillerinin nominal piyasa değerini, $K$ ise, sermaye stoğunu göstermektedir. $\mathrm{Bu}$ denklem setine, kamu bütçe kısıtı eklenmektedir:

$$
P[G+B-T]=B / r+M
$$

Yukarıda, denklem (9)'da $B$, cari piyasa fiyatı üzerinden tahvil miktarındaki değişmeyi, $B / r$ ise, tahvil stoğunun piyasa değerindeki değişmeyi göstermektedir. Denklem sistemi üç denkleme indirgenebilir.

$$
\begin{aligned}
& Y=[(C(Y+B-T(Y+B),(M+(B / r)+K))+I(r)+G] \\
& M=L(r, Y,(M+B / r+K) \\
& M+B / r=G+B-T(Y+B)
\end{aligned}
$$

Yukarıdaki, denklem (10) ve (11), statik IS ve LM denklemleridir. Denklem (12) ise, servet stoğundaki değişmelere bağlı olarak modeli, bir dengeden diğerine götürmektedir. Modelin durağan durum için çözümü, $M=B=0$ eşitliğini gerektirmektedir. Bu eşitliğin anlamı $G=T(Y)$ eşitliğidir, diğer bir deyişle bütçe 


\section{Y. KESBICC. - Ö. DÜNDAR - A. DEVRIM}

dengesi sağlanmalıdır. Daha yüksek vergi oranları ile finansmanı gerçekleştirilmeyen durağan durum çarpanı, aşağıda, denklem (13)'te verilmiştir.

$$
d Y / d G=1 / T(Y)
$$

Durağan durum çarpanı, finansman türünden bağımsızdır. Bir başka ifadeyle, sistem istikrarlı olduğu sürece, uzun dönemde tahville finansmanı sağlanan harcamalar da, en az para ile finansmanı sağlanan harcamalar kadar genişletici niteliktedir. Sistemin istikrarı, açıkların finansmanın gerçekleştirilme şekline bağlı olabilir. Parametrelerin değerlerine göre parasal finansman, sistemi istikrarlı kılabilir ya da tahville yapılan finansman, sistemi istikrarsızlığa götürebilir.

$$
\begin{aligned}
Y(t) & =f(M, B, K ; G) \\
r(t) & =g(M, B, K ; G)
\end{aligned}
$$

Yukarıdaki denklem (14) ve (15) deki $Y, t$ ve $G$ veri kabul edilerek, $M, B$ ve $K$ 'nin fonksiyonu türünde yazıldığında ve bunların kısmi türevleri alındığında, para çarpanının pozitif olduğu, tahvil çarpanının ise, belirsiz bir değer sergilediği görülmektedir (Kısmi türevler alındığında $M$ ve $B$ 'deki değişimin $Y$ 'de ne kadar değişikliğe yol açtığı görülmektedir). Denklemler (14) ve (15) aracılığıyla, denklemler (10) - (12)'de verilen dinamik sistem, doğrusal olmayan bir denklem olarak ifade edilebilmektedir.

$$
\begin{aligned}
& M=G+B-T[F(M, B, K)+B] \quad \text { parasal finansman için } \\
& B=H(M, B, K)\{G+B-T[F(M, B, K)+B]\} \text { tahville finansman için }
\end{aligned}
$$

Yukarıdaki, denklem (16)'nın türevi alındığında istikrarlılık koşulu $\left(-T^{\prime} F_{m}<0\right)$ sistemde gerçekleşmektedir. Yukarıdaki, denklem (17)'nin türevi alındığında $\left(F_{b}>\right.$ 1- $T \prime / T^{\prime}$ ) ise, istikrarlılık sorununun teorik değil, ampirik bir sorun olduğu görülmektedir (Kesbiç, 1998).

Sundararajan ve Thakur (1980) Kore ve Hindistan üzerine yaptıkları çalışmada kamu yatırımlarının rolünü aydınlatabilmek için bir büyüme modelinden yararlanmışlardır. Modelde özel yatırımların, tasarrufların ve büyümenin durumları analiz edilmektedir. Temel olarak Jorgenson'un (1971) neo-klasik yatırım modeli 
dikkate alınmıştır. Jorgenson'un modelinde sermaye-çıktı oranı, sermaye girdisinin nispi fiyatına bağlı olarak değişmektedir. Neo-Klasik teoriye göre özel yatırımın beklenen çıktı düzeyi ile pozitif, sermayenin nispi fiyatı ile negatif bir ilişkisi bulunmaktadır. Neo-Klasik modelin kullanımı, tasarruf olanaklarının yatırım üzerinde bir kısıt olarak işlev göstermesini sağlamaktadır. Gelişmiş ülkelerde de sabit sermaye yatırımları tasarruf hacmi tarafindan kısıtlanmaktadır. Modelde faiz oranlarının yatırım ve tasarruf üzerindeki etkileri de ele alınmaktadır. Çalışma, özel yatırımların, kamu sektörünün sermaye stokuna ve özel yatırıma yönelik fonlara bağlı olduğunu göstermeyi amaçlamıştır. Kamu yatırımlarının olumlu etkisi, özel sektörün çıktı üretim maliyetlerini düşürmesidir. Kamu sektörünün sermaye stoğundaki artış, özel sektörün çıktılarına yönelik talep artışına ilişkin beklentileri uyarmaktadır. Kamu sektörünün reel sabit yatırımlarındaki artış, kamu sektörü çıktısını, özel sektörün beklenen ve gerçekleşen çıktısı ise, toplam iç tasarrufları arttırırken, kamu yatırımının finansmanı için tasarrufların bir kısmının kullanımını gerektirmektedir. Kamu yatırımlarının özel sektör için gerekli olan tasarrufları kullanması durumunda, dışlama etkisi meydana gelmekte, özel sabit yatırımlar azalmaktadır. Yapılan ampirik testte Hindistan'a göre Kore'de kamu sektörünün sermaye stoğunun, özel sektörün çıtı beklentileri üzerindeki etkisi büyüktür. Faiz oranlarının, Hindistan'da tasarruflar üzerinde etkili olduğu, Kore'de ise anlamlı bir etkisinin olmadığı saptanmıştır. Faiz oranları, Hindistan'da tasarruflar üzerinde olumlu etkide bulunurken, yatırımlar üzerinde olumsuz etkide bulunmaktadır. Uygulanan simülasyonlarda Hindistan için kamu yatırımlarındaki artış, ilk aşamada özel yatırımların azalmasına neden olmuştur. İzleyen dönemlerde ise, kamu yatırımı tarafından oluşturulan ek kaynaklar özel yatırımları arttırmaktadır. $\mathrm{Bu}$ artışlar, ilk dönemde meydana gelen dışlama etkisini ancak uzun dönemde dengeleyebilmektedir. Yine de ilk dönem dışlama etkisinin kısmi olduğu, artan kamu yatırımının ortalama olarak yatırımı arttırdığı gözlenmektedir. Kore için ise, kamu yatırımları hem ilk dönemde hem de izleyen dönemlerde olumlu etkide bulunmaktadır. 


\section{Y. KESBİÇ. - Ö. DÜNDAR - A. DEVRİM}

Wai ve Wong (1982) çalışmalarında esnek hızlandıran yatırım modelinden faydalanmışlardır. Modelde özel yatırım; arzulanan özel sermaye ile geçmiş dönem özel sermaye stoğunun farkı ve geçmiş dönem özel sermaye stoğuna göre değişen yenileme yatırımlarının toplamının fonksiyonudur. Malezya, Yunanistan, Tayland, Meksika ve Kore için, en küçük kareler yöntemiyle, aşağıdaki, denklem (18) ve (19), test edilmiştir. ${ }^{4}$

$$
\begin{aligned}
& I P_{t}=a_{0}+a_{1} Q P_{t}+a_{2} \Delta D C P_{t}+a_{3} C M P_{t}+a_{4} K P_{t-1}+u_{3 t} \\
& I P_{t}=b_{0}+b_{1} I G_{t}+b_{2} \Delta D C P_{t}+b_{3} C M P_{t}+b_{4} K P_{t-1}+u_{4 t}
\end{aligned}
$$

Denklem (18) ve (19) da; $I P$ özel yatırımları, $Q P$ özel sektör çıktısını, $D C P$ banka sisteminin özel sektörden alacaklarını, $C M P$ özel sektöre yönelen net sermaye akımlarını, $I G$ kamu yatırımlarını ve $K P$ özel sektör sermaye stoğunu göstermektedir. Çalışmada Yunanistan, Kore ve Malezya'da kamu yatırımlarının özel yatırımlara olumlu etkisi olduğu, Tayland ve Meksika'da ise, kamu yatırımlarının dışlama etkisine yol açtığı belirlenmiştir.

Blejer ve Khan (1984) çalışmalarında esnek hızlandıran modelinden yararlanarak oluşturdukları modelde, altyapı yatırımları ve diğer kamu yatırımları arasında ayrıma gitmişler, özel yatırımlar üzerinde kamu yatırımlarının, devresel etmenlerin, banka kredilerindeki değişimlerin, reel net özel sermaye akımlarının ve beklenen çıktının etkilerini test etmişlerdir. 24 gelişmekte olan ülke için 1971-1979 dönemi verileri kullanılarak yapılan test sonucunda, kamu yatırımları hacmindeki değişimin dışlama etkisine yol açtığı görülmüsştür.

Khan (1988) çalışmasında esnek hızlandıran yatırım modelini temel almıştır. Modelde arzu edilen sermaye stoğu ile beklenen çıtı düzeyi arasında ilişki bulunmaktadır. Gerçekleşen özel sermaye stoğu, ilgili dönemde arzulanan stok ile

${ }^{4}$ Yunanistan ve Kore için test edilen denklemler, yedek akçeleri $(R E)$ de içermektedir. Denklem (19) makalede ayrıca aşağıdaki gibi denklem (20) olarak ifade edilmektedir.

$I P_{t}=c_{0}+c_{1} I G_{t}+c_{2} F P_{t}+c_{3} K P_{t-1}+u_{5 t}$

Maliyetleri açısından bir fark olmadığında, özel sektöre verilen krediler ve net sermaye akımları arasında yatırımcı açısından bir fark yoktur. Bu nedenle denklem (20)'de bu iki değişkenin toplamı FP olarak ifade edilmektedir. 
geçmiş dönemde gerçekleşen stok farkına göre belirlenmektedir. Aşağıda, denklem (21)'de görüldüğü gibi, özel yatırım (IP) ile özel sermaye stoğundaki değişim ve belirli bir oranda $(\delta)$ yıpranan geçmiş dönem sermaye stoku arasında fonksiyonel bir ilişki bulunmaktadır.

$$
I P_{t}=\Delta K_{t}+\delta K_{t-1}
$$

Gecikme operatörünün $(L), K_{t}$ ile çarpımı sonucu $K_{t-1}$ 'in elde edileceği kabul edilerek, denklem (21), aşağıdaki gibi denklem (22) olarak da ifade edilebilmektedir.

$$
I P_{t}=\alpha \beta[1-(1-\delta) L] K^{*}
$$

Aşağıda, denklem (23)'te görüldüğü gibi, modelde gerçekleşen özel yatırımdaki değişim ile arzulanan özel yatırım ile geçmiş dönemde gerçekleşen özel yatırım farkı arasında fonksiyonel bir ilişki söz konusudur.

$$
\Delta I P_{t}=\beta\left[I P^{*}-I P_{t-1}\right]
$$

$\beta$ katsayısı, özel yatırımcıların arzulanan ve gerçekleşen yatırımlar arasındaki tepkilerini göstermektedir. Özel yatırımcıların tepkisi; piyasa koşullarına, banka sisteminin sunduğu kredi olanaklarına ve kamu sektörü yatırım düzeyine bağlıdır. Çalışmanın ampirik kısmında, Pakistan için 1959-1986 dönemi verileriyle, doğrusal en küçük kareler yöntemi ile bu üç etmenin özel yatırımlar üzerindeki etkisi test edilmiştir. Piyasa koşullarının etkisinin ölçülmesinde GSYİH'nın gerçekleşen ve trend düzeyi arasındaki fark dikkate alınmıştır. ${ }^{5}$ Piyasa koşullarının, özel yatırımlar üzerinde önemli ölçüde etkili olduğu görülmüştür. Kredilerin de önemli ölçüde etkili olması, para politikalarının özel yatırımlar üzerindeki etkisini göstermektedir. Kamu yatıımlarının özel yatırımlar üzerinde çekme etkisi yarattığı sonucuna ulaşılmıştır.

\footnotetext{
${ }^{5}$ Çalışmada GSYİH trend düzeyi, tam kapasite düzeyi olarak kabul edilmiştir. Gerçekleşen GSYIH trend düzeyini geçtiğinde arzulanan ve gerçekleşen yatıım arasındaki açı̆̆a yatırımcıların tepkisi görece yavaş, gerçekleşen GSYİH trend düzeyinin altında kaldığında ise görece hizlı olmaktadır.
} 


\section{Y. KESBİÇ. - Ö. DÜNDAR - A. DEVRİM}

Aschauer (1988) çalışmasında kamu yatırımlarının özel sermayenin verimliliğine etkisini analiz için geliştirilmiş neo-klasik üretim fonksiyonunu ele almıştır. Fonksiyon, özel sermayenin marjinal ürününü, nüfusun kamu sermaye stoğuna oranını ve nüfusun özel sermaye stoğuna oranını içermektedir. İstatistik açısından nüfus ele alınmakla birlikte, söz konusu oranlar, teorik olarak sermayeemek oranlarıdır. Fonksiyon, Amerika için 1953-1985 dönemi verileri kullanılarak, doğrusal en küçük kareler, birinci sıra otoregresyon ve araçsal değişkenler yöntemleriyle test edilmiştir. Sonuçlara göre, kamu sermaye stoğu, özel sermayenin getiri oranını arttırmakta ve çekme etkisi oluşmaktadır.

Easterly'in (1989) çalışmasında Solow'un (1956) modelindeki gibi kamu ve özel yatırımlar, sektörlerin tasarruf eğilimlerinin ve borçlanma eğilimlerinin bir fonksiyonudur. Kamu kesimi, vergi gelirlerinin bir kısmını sabit oranda tasarruf etmektedir. Yıpranma ve borç faizi ise, kamu sermaye birikimi üzerinde negatif etkide bulunmaktadır. Yeni borçlanma, büyüme hızı ile borç-çıktı oranının çarpımına eşittir. $\mathrm{Bu}$ da yine borç-sermaye oranı ile kamu sermaye oranının çarpımına eşit olmaktadır. Özel sermaye birikimi için de aynı fonksiyonel ilişkiler söz konusu olmakta; özel gelir, toplam çıktı ile vergi gelirleri arasındaki fark olarak ifade edilmektedir. Durağan aşamada özel sermaye ve kamu sermaye stoğu artış hızları, büyüme hızına eşit olmalıdır.

Modelde kurulan simülasyonda ulaşılan ilk sonuçlardan biri, vergi oranı ile vergi geliri arasında Laffer Eğrisi'nde özetlenen ilişkinin varlığıdır. Vergi oranı, sıfırdan itibaren yükseldiğinde vergi geliri yükselmekte, vergi oranındaki artış vergi miktarındaki düşüşü karşılamaktadır. Vergi oranındaki artışa bağlı olarak, kamu sermaye stoğu arttığından büyüme hızı artmaktadır. Vergi oranlarındaki artış bir noktadan sonra, kamu gelirinin ve kamu sermayesini arttırmakla birlikte, büyüme hızını yavaşlatmaktadır. Bu noktadan sonra vergi oranlarındaki artış, özel sektör üzerinde dışlama etkisinde bulunduğundan, kamu gelirlerinin ve kamu sermayesinin azalmasına neden olmaktadır. Vergilerdeki artışın, kamu sermaye artı̧̧ında ve dolayısıyla büyüme üzerinde olumlu etkide bulunabilmesi, kamu vergi gelirlerinin ne ölçüde tasarrufa yönlendirildiğine bağlıdır. Kamu kesiminin hiç 
tasarrufa gitmemesi durumunda vergi oranındaki her artış, büyüme hızını yavaşlatmaktadır.

Ramirez (1994) çalışmasında geliştirilmiş neo-klasik üretim fonksiyonundan yararlanarak oluşturduğu modelde istihdamın, özel sermaye stoğunun ve kamu sermaye stoğunun reel çıktı düzeyine etkisini analiz etmiştir. Çalışmada esnek hızlandıran yatırım modelinden faydalanılmıştır. Ampirik testte kullanılan aşağıdaki denklem (24)'de $I P$ özel yatırımı, $\sigma$ geçmiş dönem sermaye stoğundaki yıpranmayı, $G A P$ çıktı açığını, $\triangle R C P$ özel sektörün kullanabildiği reel kredi akımını, $R G I$ kamu yatırımını, $E X$ reel döviz kurunu ve $Y^{*}$ arzulanan reel çıktı düzeyini göstermektedir. $L$ gecikme operatörü ve $D$ kukla değişkendir.

$$
I P_{t}=\alpha \beta[1-(1-\sigma) L] Y_{t}^{*}+\beta \alpha_{1} G A P+\beta \alpha_{2} \Delta R C P_{t}+\beta \alpha_{3} R G I_{t}+\beta \alpha_{4} E X_{t}+\beta \alpha_{5} D_{t}+
$$
$(1-\beta) I P_{t-1}$

Denklem (24), Meksika için 1950-1988 dönemi verileriyle test edilmiştir. Sonuç olarak, reel kredi akımı ve kamu yatırımlarının, özel yatırımlara pozitif etkisi olduğu, reel döviz kurunun ise, özel yatırımlara negatif etkisi olduğu görülmüştür.

Oshikoya (1994) çalışmasında kurduğu modelde, özel yatırımın GSYİH'ya oranı ile reel GSYİH'daki yüzdesel değişimin, kamu yatırımlarının GSYİH'ya oranının, özel sektöre verilen kredilerdeki değişimin, tüketici fiyat endeksindeki yüzdesel değişimin, reel döviz kurunun, geçmiş dış borçların ihracata oranının ve geçmiş özel yatırımın GSYİH'ya oranının fonksiyonel ilişkilerini analiz etmişlerdir. Afrika için yapılan çalışmada kamu yatırımlarının özel yatırımlar üzerinde çekme etkisine yol açtığı görülmüştür.

Looney (1995) çalışmasında Pakistan için Granger nedensellik testiyle, altyapı yatırımlarını kapsamayan kamu yatırımlarının imalat sektöründe dışlama etkisine yol açtığı, imalat sektörü dışındaki diğer sektörler için finansal ya da reel dışlama etkisinin olmadığı sonucuna ulaşmıştır.

Serven (1996) çalışmasında kullandığı modelinde ekonomi, kamu sektörü ve özel sektör olmak üzere iki sektörden oluşmaktadır. Kamu sektörü, iki mal üretmektedir. Bu mallardan birincisi, kısaca “altyapı hizmetleri” denilen, özel 


\section{Y. KESBİÇ. - Ö. DÜNDAR - A. DEVRİM}

sektörün kullanabildiği ara mal niteliğindeki üretken girdilerdir, bunların üretimi için yalnızca altyapı sermayesi gerekmektedir. Bu mallardan diğeri ise, herhangi bir altyapı hizmeti sunmamakta ve bu malın üretimi için sermaye ve emek kullanılmaktadır. Özel sektör, emek, sermaye ve altyapı hizmetlerini kullanarak, tek bir nihai mal üretmektedir. Kamu ve özel sektörün ürettiği nihai mallar, tam ikame mallardır, dolayısıyla bu malların özel tüketimleri açısından kamu sektörü ve özel sektör rekabet içerisindedir.

Modelde kamu sektörünün nihai mal için ayırdı̆̆ sermayenin $\operatorname{arttığ}$, dolayısıyla çıktının arttığı ve kamu nihai malının nispi fiyatının düştüğü varsayılmaktadır. Fiyattaki bu düşüş, özel nihai mala yönelik talebin, kamu nihai malına yönelmesine yol açacağından kamu sektöründeki istihdam artmaktadır. Ayrıca, kamu nihai malının fiyatı düştüğünde, kamu firmaları çıktısı cinsinden reel ücret yükseleceğinden, kamu istihdamı azalmaktadır. Net sonuç, iki etmenden birinin diğerine üstün gelmesiyle belirlenmektedir. Altyap1 sermaye stoğu arttığında ise, özel sektörde emek ve sermayenin verimliliği, dolayısıyla özel firmaların çıktıları artmakta ve özel nihai malın nispi fiyatı düşmektedir.

Çalışmanın ampirik kısmında, fonksiyonel ilişsinin gösterildiği aşağıdaki, denklem (25)'te $k_{p r}$ özel sektör yatırımlarını, $k_{g}$ kamu sektörü yatırımlarını, $z$ altyapı stoğunu, $p_{k}$ sermaye mallarının nispi fiyatını ve $c r_{p r}$ özel sektör için reel kredi stoğunu göstermektedir. Analizde altyap1 stoğunun ve reel kredi stoğunun pozitif, sermaye mallarının nispi fiyatının ise, negatif etkisi olacağı beklenirken, kamu sektörü yatırımlarının net etkisi belirli değildir.

$$
k_{p r}=\varphi\left(k_{g}, z, p_{k}, c r_{p r}\right)
$$

Gelişmekte olan ülkelerde kamu kesiminin altyapı yatırımları yanında, özel sektörün ticari ve sınai yatırımları da gerçekleşmektedir. Çalışmada Hindistan için alt yapı yatırımlarının uzun dönemde özel yatırımlar üzerinde çekme etkisine, ticari ve sınai yatırımların ise, dışlama etkisine yol açtığı sonucuna ulaşmıştır. Her iki tür yatırımın da kısa dönemde, dışlama etkisi oluşturduğu görülmüştür. 
Argimon vd. (1997) çalışmalarında oluşturdukları modelde, ekonomik birimlerin iki dönem yaşadıkları varsayılmaktadır. Bu birimler, yalnızca ilk dönemde emek arz etmekte ve ücret ile geçinmektedir. Birimlerin tüketim düzeyleri, ücret ile vergi ve tasarrufların arasındaki farka eşittir. İkinci dönemde ise, vergi ödeme yükümlülügü olmayan birimler, tasarrufları yoluyla geçimlerini sürdürmektedir. Tasarruf hacmi, faiz oranına bağlı olarak değişmektedir. Kamu vergilerle, ekonomik birimlerin fayda fonksiyonunda yer alan kamu mallarını ve özel sektör üretiminde kullanılan üretken girdileri üretmektedir. Modelde birimler, özel sektör mallarını, kamu mallarına belirli bir katsayı üzerinden tercih etmektedir.

Kamu ve özel sektör malları bir dönem içerisinde tamamen değer yitirmekte, ikinci dönemde sermaye, birinci dönemde yapılan tasarrufa eşit olmaktadır. Kamu tüketim harcamalarının özel yatırımlar üzerindeki etkisi, vergilerin tasarruflar üzerindeki etkisine ve kamu hizmetlerinin ne ölçüde özel tüketimin tamamlayıcısı ya da ikamesi olmasına göre değişmektedir. Vergilerin tasarruflar üzerindeki negatif etkisi nedeniyle kamu yatırımlarındaki artış, özel yatırımlar üzerinde dışlama etkisine yol açmaktadır. Buna karşın, kamu sermayesi, özel sermayenin verimliliğini arttırdığında, kamu yatırımları, özel yatırımlar üzerinde bir çekme etkisine neden olmaktadır.

Çalışmanın ampirik kısmında kullanılan aşağıdaki, denklem (26) ve (27)'de, $t$ zamanı, $j$ ülkeyi, $i$ özel yatırımları, $i_{g}$ kamu yatırımlarını, $c_{g}$ kamu tüketimini, $f_{k}$ özel sermayenin marjinal verimliliğini, $k$ özel sermaye stoğunu ve $k_{g}$ altyapı sermayesini göstermektedir.

$$
\begin{aligned}
& i_{j t}=a_{1 j t}+a_{2 j t} f_{k j t}+a_{3 j t} \dot{l}_{g t}+a_{4 j t} c_{g j t}+e_{1 j t} \\
& \ln f_{k j t}=b_{1 j t}+b_{2 j t} \ln k_{j t}+b_{3 j t} \ln k_{g j t}+e_{2 j t}
\end{aligned}
$$

Çalışmada 14 OECD ülkesinde panel veri yöntemiyle kamu yatırımları ve özel yatırımlar arasındaki ilişki test edilmiştir. Sonuç olarak, kamu yatırımlarının özel yatırımlara olumlu etkisinin olduğu, yatırımlar dışındaki kamu yatırımlarının dışlama etkisine neden olduğu belirlenmiştir. 


\section{Y. KESBİÇ. - Ö. DÜNDAR - A. DEVRİM}

Nazmi ve Ramirez (1997) Solow'un (1956) modelinden yararlanarak oluşturdukları modelde emek gücünün, özel sermaye stoğunun, kamu sermaye stoğunun ve diğer etmenlerin reel çıktı düzeyine etkisini, Meksika için analiz etmektedirler. Çalışmada verimlilik artışı, emeğin çıktı esnekliği, kamu ve özel sermayenin marjinal verimliliği ile kamu tüketim harcamalarının ve ihracatın çıktı esnekliğinin, çıktı büyüme hızına etkisini ele almışlardır. Kamu tüketim harcamaları ve ihracat verileri, ikinci aşamada modelden çıkarılmıştır. Kamu yatırımlarının özel yatırımlar üzerindeki etkisine modelde yer verebilmek amacıyla özel yatırımlar ile geçmiş dönem kamu ve özel yatırımları, geçmiş dönem büyüme hızı, faiz oranları, kamu tüketimi ve ihracat arasında fonksiyonel bir ilişki kurulmuştur. Çalışmada Meksika için 1950- 1990 dönemi verileri kullanılarak, Phillips-Perron testi ve iki aşamalı en küçük kareler yöntemi uygulanmıştır. Analiz sonucunda, özel ve kamu yatırımlarının büyüme üzerinde önemli etkileri olduğu, önceki çalışmalardan farklı olarak emek gücünün büyüme sürecinde önemli rolü olduğu, çıktı ve faiz oranlarının özel yatırımlar üzerinde etkili olduğu görülmüştür. Kamu yatırımlarının, özel yatırımlar üzerinde dışlama etkisi oluşturmasına karşın, bu yatırımların büyüme üzerinde olumlu etkileri olduğu belirlenmiştir.

Kesbiç (1998) Blinder-Solow modelinden yararlandığı çalışmasında, Türkiye'de özellikle 1987 yılı sonrasında kamu açıklarının finansmanı için kamunun önemli ölçüde fon talep etttiğini, dolayısıyla mali piyasalarda özel sektörün kullanabileceği fon arzının azaldığını belirtmektedir. Sonuç olarak, iç borçlanmanın daraltıcı değil, genişletici etkide bulunduğu, ancak genişlemenin reel değil, nominal nitelikte olduğu belirlenmiştir.

Bahmani-Oskooee (1999) çalışmasında oluşturduğu modelde reel gelirin, faiz oranının ve bütçenin özel yatırımlar üzerindeki etkilerini, ABD için 1947- 1992 dönemi verilerini kullanarak, Johansen-Juselius eşbütünleşme tekniğiyle araştırmıştır. Sonuç olarak, bütçe açıklarının uzun vadede özel yatırımlar üzerinde çekme etkisine yol açtığı belirlenmiştir. 
Ahmed ve Miller (2000) çalışmalarında iki denklemden yararlanmışlardır. Birinci denklemde; vergilerin, kamu yatırımlarının, dış ticaretin (ithalat ve ihracat toplamı) GSYİH içerisindeki payı ile özel yatırımların GSYİH içerisindeki payı arasında bir fonksiyonel ilişki kurulmaktadır. İkinci denklemde; kamu yatırım harcamaları toplu olarak değil, savunma harcamaları, eğitim harcamaları, sağlık harcamaları, sosyal güvenlik harcamaları ve ulaşım ve iletişim harcamaları olarak, alt kategorilere ayrılmıştır. Çalışmada 1975-1984 dönemi verileriyle, 23 gelişmekte olan ve 16 gelişmiş ülke için, doğrusal en küçük kareler yöntemine başvurulmuştur. Sonuç olarak, vergi ile finansmanı yapılan kamu yatırımlarının, borçla finansmanı yapılan kamu yatırımlarından daha çok dışlama etkisine yol açtığ1; sosyal güvenlik harcamalarının bütün ülkelerde özel yatırımları azaltırken, gelişmekte olan ülkelerde ulaşım ve iletişim harcamalarının özel yatırımları olumlu etkilediği görülmüştür.

Hyder (2001) çalışmasında geliştirilmiş neo-klasik üretim fonksiyonundan yararlanmış, Pakistan için 1964-2001 dönemi verilerini kullanarak, multivariate time series yöntemiyle dışlama etkisini incelemiştir. Sonuç olarak, uzun dönemde özel yatırımlar ve kamu yatırımların büyümeye etkisinin olumlu olduğu, kamu yatırımları ve özel yatırımlar arasında ise, tamamlayıcılık ilişkisi olduğu görülmüştür.

Naqvi (2001) çalışmasında Pakistan için 1964- 2000 dönemi verileriyle, eşbütünleşme tekniğini kullanarak, ekonomik büyüme, kamu yatırımları ve özel yatırımlar arasındaki ilişkiyi incelemiştir. Analiz sonucunda kamu yatırımlarının özel yatırımlar üzerinde çekme etkisi oluşturduğu gözlenmiştir.

Yavuz (2001) çalışmasında Türkiye için 1990-2001 dönemi verilerini kullanarak, hata düzeltme modeline başvurmuştur. Sonuç olarak, kamu yatırım harcamalarının ve faiz oranlarının özel yatırımları dışladığı görülmüştür.

Naqvi ve Tsoukis (2003) çalışmalarında esnek hızlandıran yatırım modelinden yararlanarak, reel GSYİH'daki değişimlerin ve kamu yatırımlarının özel yatırımlara etkisini 1971-2000 dönemi verilerini kullanarak, beş Asya ülkesi için 


\section{Y. KESBİÇ. - Ö. DÜNDAR - A. DEVRİM}

test etmişlerdir. Sonuç olarak, kamu yatırımlarının Pakistan'da çekme etkisine, Tayland'da ise, dışlama etkisine yol açtığı görülmüştür. Bengladeş'te kamu yatırımlarının hacmi özel sektör tarafından belirlenirken, Hindistan ve Malezya için, kamu yatırımları ve özel yatırımlar arasında nedensellik ilişkisi belirlenmemiştir.

Berber (2003) çalışmasında Türkiye için 1963-1999 dönemi verilerini kullanarak, eşbütünleşme yöntemi ve hata düzeltme modeline başvurmuştur. Sonuç olarak, büyüme ile kamu ve özel yatırımları arasında karşılıklı nedensellik ilişkisi olduğu ve büyüme üzerinde özel yatırımların daha etkili olduğu görülmüştür.

Şimşek (2003) çalışmasında genişletilmiş basit yatırım hızlandıran modelini kullanmış, Türkiye için 1970- 2001 verileriyle, çeşitli kamu yatırımlarının özel yatırımlara etkisini analiz etmiştir. Sonuç olarak, kamu altyapı yatırımlarının ve faiz ödemelerini içeren kamu yatırımlarının özel yatırımlar üzerinde dışlama etkisine yol açtığ 1 görülmüştür.

Kar ve Taban (2003) çalışmalarında çeşitli kamu yatırım harcamalarının büyüme üzerindeki etkisini, Türkiye için 1971- 2000 dönemi verilerini kullanarak, eşbütünleşme tekniğiyle analiz etmişlerdir. Sonuç olarak, eğitim ve sosyal güvenlik harcamalarının büyümeyi olumlu, sağlık harcamalarının ise, büyümeyi olumsuz etkilediği ve altyapı harcamalarının istatiksel olarak anlamlı olmadığ 1 belirlenmiştir.

Uysal ve Mucuk (2003) çalışmalarında kamu yatırımlarının özel yatırımlara etkisini, Türkiye için 1975-2000 dönemi verilerini kullanarak, en küçük kareler yöntemi ile test etmişlerdir. Sonuç olarak, kamu yatırım harcamalarının özel yatırımları dışladığı görülmüştür.

Ertan (2004) çalışmasında Türkiye için 1989- 2003 dönemi verilerini kullanarak, zaman serilerinde çoklu regresyon analiziyle, kamu yatırımları, iç borç stoğu ve özel sektöre bankalar tarafından verilen borçların özel yatırımlara etkisini test etmiştir. Analiz sonucunda, özel yatırımların, kamu yatırımları ve iç borç stoğundan olumsuz etkilendiği görülmüştür. 
Kuştepeli (2005) çalışmasında Dickey Fuller birim kök testi ve Johansen eşbütünleşme yöntemini kullanarak, iki model kurmuştur. Birinci modelde; özel yatırım üzerinde reel faiz oranının, reel gelirin (GSMH) ve reel kamu yatırımlarının etkileri, Türkiye için 1967- 2003 dönemi verileriyle test edilmiştir. İkinci modelde; özel yatırımlar üzerinde reel faiz oranının, reel gelirin ve reel bütçe açığının etkileri, Türkiye için 1963- 2003 dönemi verileriyle test edilmiştir. Sonuç olarak, özel yatırımlar ile reel faiz oranları arasında negatif, özel yatırımlar ile reel gelir arasında pozitif ilişki olduğu, bütçe açıklarındaki artışın özel sektör üzerinde uzun dönemde dışlama etkisine yol açtığ 1 görülmüştür.

Yavuz (2005) çalışmasında kamu yatırımlarının ve faiz oranının özel yatırımlara etkisini, Türkiye için 1980-2003 dönemi verilerine göre test etmiştir. Sonuç olarak, kamu yatırımlarının özel yatırımlar üzerinde çekme etkisine yol açtığ sonucuna ulaşılmıştır.

Erden (2005) çalışmasında Türkiye için 1968-1998 dönemine ait verilerle, esnek hızlandıran yatırım modeli ve vektör hata düzeltme modelini kullanmıştır. Sonuç olarak, reel GSMH'nın özel yatırımlar üzerinde olumlu etkisi olduğu, reel kamu yatırımlarının ise, dışlama etkisine yol açtığı görülmüştür.

Saeed vd. (2006) çalışmalarında geliştirilmiş̧ neo-klasik üretim fonksiyonundan yararlanarak, VAR modeliyle, Pakistan için kamu yatırımlarının özel yatırımlar üzerindeki etkisini analiz etmişlerdir. Sonuç olarak, tarım sektörü açısından çekme etkisinin, imalat sektörü açısından ise, dışlama etkisinin olduğu görülmüştür.

Mitra (2006) çalışmasında yapısal vektör otoregresyon (SVAR) modeliyle, Hindistan için 1969- 2005 dönemi verilerini kullanarak, kısa dönemde kamu yatırım harcamalarının özel harcamalar üzerinde dışlama etkisine yol açtığı sonucuna ulaşmıştır.

Başar ve Temurlenk (2007) çalışmalarında yapısal VAR modelini kullanarak, Türkiye için 1980 sonrası dönemde kamu yatırımlarının özel yatırımlar üzerindeki dışlama etkisini analiz etmişlerdir. Sonuç olarak, dışlama etkisinin düşük düzeyde olduğu görülmüştür. 


\section{Y. KESBİÇ. - Ö. DÜNDAR - A. DEVRİM}

Altay ve Altın (2008) çalışmalarında Türkiye için 1980-2005 dönemi verileriyle, toplam kamu yatırımlarının büyüme ve toplam yatırımlar üzerindeki etkisini, Pati Ram'ın geliştirdiği iki sektörlü üretim fonksiyonu ve en küçük kareler yöntemini kullanarak, analiz etmişlerdir. Sonuç olarak, kısa dönemde kamu yatırımlarının toplam yatırımlar üzerinde olumlu etkisi olduğu, uzun dönemde ise, kamu büyüklüğündeki artış nedeniyle dışlama etkisinin meydana geldiği görülmüştür.

Hatano (2010) çalışmasında Japonya için 1957-2004 dönemi verilerini kullanarak, Johansen eşbütünleşme analizi ve Granger nedensellik testini uygulayarak, kamu yatırımlarının ilk yıl özel sektör yatırımlarını dışladığı ancak devam eden yıllarda tamamladığı bulgusuna ulaşmıştır.

Dianne ve Lee (2011) çalışmalarında Endonezya için 1997-2010 dönemi çeyrek dönemlik verilerini kullanarak, kamu yatırımları ile özel sektör yatırımları arasındaki ilişkiyi vektör hata düzeltme modeliyle araştırmışlardır. Kamu yatırımlarının özel sektör yatırımlarını dışladığı sonucuna ulaşmışlardır.

Hassan vd. (2011) çalışmalarında Malezya için 1976- 2006 dönemi verilerini kullanarak tarım, ticaret ve imalat, ulaştırma ve haberleşme ile inşaat sektörlerindeki tamamlama ve dışlama etkisini, panel veri yöntemiyle araştırmışlardır. Söz konusu sektörlerdeki kamu yatırımlarının aynı sektörlerdeki özel sektöryatırımlarını pozitif yönde etkilediği sonucuna ulaşmışlardır.

Birian vd. (2012) çalışmalarında Zimbabve için 1967- 2004 dönemi verilerini kullanarak, vektör hata düzeltme modelinin (VECM) uygulanmasıyla, kamu yatırımlarındaki kısa dönemli değişikliklerin özel sektör yatırımlar üzerinde tamamlayıcı etkisi olduğu sonucuna ulaşmışlardır.

Altunöz (2013) çalışmasında Türkiye için 1989-2004 dönemi verilerini kullanarak, RDL yöntemi ile, kamu iç borçlanmasının özel yatırımları dışlama etkisini test etmiştir. Sonuç olarak, ilgili dönemde dışlama etkisi olduğu belirlenmiştir. 
Tülümce ve Buyrukoğlu (2013) çalışmalarında Türkiye için 1980- 2010 dönemi verilerini kullanarak, Johansen eşbütünleşme ve Granger nedensellik testleriyle, özel yatırımlar ile kamu yatırımları arasındaki ilişkiyi analiz etmişlerdir. Sonuç olarak, özel yatırımlardan kamu yatırımlarına doğru nedensellik ilişkisi olduğu ve uzun dönemde faiz oranlarının özel yatırımları olumsuz etkilediği görülmüştür.

\section{DIŞLAMA ETKİSININN TÜRKIYYE İÇİN ANALİi̇}

Çalışmada Türkiye'de 1986- 2014 dönemi için kamu yatırımlarının özel yatırımları dışlama etkisi araştırılmıştır. Türkiye için yapılan analizde, cari fiyatlar ile özel sabit sermaye yatırımları, cari fiyatlar ile kamu sabit sermaye yatırımları ve cari fiyatlar ile iç borç stoku yıllık verileri; Türkiye Cumhuriyeti Merkez Bankası Elektronik Veri Dağıtım Sisteminden (EVDS) elde edilen İstanbul Ticaret Odası 1968 y1lı Toptan Eşya Fiyat Endeksi (TEFE) y1llık verileri kullanılarak, reel hale getirilmiştir. Böylece çalışmada söz konusu reel hale getirilmiş veriler ve iç borç faiz oranı yıllık verileri kullanılmıştır. Ayrıca, özel sabit sermaye yatırımlarının, kamu sabit sermaye yatırımlarının ve iç borç stokunun GSYİH'ye oranı, analizde bu değişkenlerin GSYIHH içerisindeki paylarının kullanılması temel alındığı için tarafımızca belirlenmiştir.

Özel sabit sermaye yatırımları, kamu sabit sermaye yatırımları, iç borç faiz oranı ve GSYİH değişkeni kalkınma bakanlığından, iç borç stoku değişkeni ise, hazine müsteşarlığından elde edilmiştir.

Analizde değişkenlerin isimleri, kolaylık olması nedeniyle kısaltılmış, her bir değişkenin GSYIHH'ye oranı, değişkenlerin altına GSYİH yazılarak, ifade edilmiştir. Özel sabit sermaye yatırımları (ÖY), kamu sabit sermaye yatırımları (KY), iç borç stoku (IBS) ve iç borç faiz oranı (IBBF) şeklinde gösterilmiştir.

Değişkenler arasında ekonometrik olarak anlamlı ilişkiler elde edilebilmesi için, analiz yapılan serilerin durağan seriler olması gerekmektedir (Gujarati, 2003: 817). Çalışmada zaman serilerinin durağanlığını belirlemek için son dönemlerde geliştirilen Ng-Perron birim kök testinin kullanılması tercih edilmiştir. Ng-Perron birim kök testleri, özellikle Phillips-Perron (PP) testlerinde ortaya çıkan hata 


\section{Y. KESBİÇ. - Ö. DÜNDAR - A. DEVRİM}

teriminin hacmindeki boyut dağılımı çarpıklığını düzeltmek için M-testleri olarak geliştirilen yeni birim kök testleridir. Bu testler, Phillips-Perron $\mathrm{Za}$ ve $\mathrm{Zt}$ testlerinin değiştirilmiş̧ (modifiye edilmis) hali olan MZa ve MZt testleri, Bhargava testinin değiştirilmiş (modifiye edilmis) hali olan MSB testi ve ADF-GLS testinin değiştirilmiş (modifiye edilmis) hali olan MPT testi olmak üzere, dört farklı birim kök testini kapsamaktadır. Bu nedenlerle çalışmada Ng-Perron birim kök testi kullanılmış, söz konusu teste göre değişkenlerin birinci farkları alındığında durağan oldukları tespit edilmiştir (Sevüktekin ve Nargeleçekenler, 2007: 365).

Johansen eşbütünleşme testiyle, değişkenlerin eşbütünleşik olma durumlarının araştırılabilmesi için zaman serilerinin durağan olmaları gerekmekte, seriler birinci farkları alındığında durağan oldukları için söz konusu test uygulanabilmiştir. Johansen eşbütünleşme testi uygulandıktan sonra, EKKY uygulanmıştır. Son olarak, çalışmada kullanılan değişkenler arasındaki nedensellik ilişkisinin yönünü belirlemek için Granger nedensellik testi uygulanmıştır.

\subsection{Ng- Perron Birim Kök Testi Sonuçları}

Aşağıdaki tablolarda Ng- Perron Birim Kök testinin sonuçları yer almaktadır. Modelde kullanılan değişkenlerin \% 5 seviyesinde düzey değerinde durağan olmadıkları, ancak birinci farkları alındığında durağan oldukları görülmüştür.

Aşağıda tablo 2'de yer alan düzeyde NG- birim kök testi sonuçları, çalışmada kullanılan değişkenlerin düzey değerlerinde durağan olmadıklarını göstermektedir. \% 5 anlamlılık seviyesinde $\mathrm{MZ}_{\mathrm{a}}$ ve $\mathrm{MZ}_{\mathrm{t}}$ testleri için hesaplanan istatistik değerleri, Ng- Perron (2001) tarafından hesaplanan kritik değerlerden küçük olduğu için temel hipotez olan birim kökün varllğı hipotezi reddedilememektedir. MSB ve MPT testleri için hesaplanan istatistik değerleri ise, Ng ve Perron (2001) tarafindan hesaplanan kritik değerlerden büyük olduğu için, temel hipotez olan birim kökün yokluğu hipotezi reddedilmektedir. $\mathrm{MZ}_{\mathrm{a}}$ ve $\mathrm{MZ}_{\mathrm{t}}$ ile $\mathrm{MSB}$ ve MPT testleri, temel hipotez açısından farkl11ık göstermektedir. Bu durumda birim kökün var olduğu ortaya çıkmaktadır. Değişkenlerin \% 5 anlamlılık seviyesinde düzey değerinde durağan olmadıkları görülmüştür. 
Dokuz Eylül Üniversitesi İktisadi ve İdari Bilimler Fakültesi Dergisi Cilt:31, Sayl:2, Yıl:2016, ss. 59-94

Tablo 2. Sabit Terimli Olma Durumuna Göre Ng- Perron Birim Kök Testi

\begin{tabular}{|c|c|c|c|c|c|}
\hline \multirow{9}{*}{ Düzey } & Değişken & $\mathbf{M Z}$ & $\mathbf{M Z}$ & MSB & MPT \\
\hline & ÖYYGSYİH & -4.99455 & -1.45791 & 0.29190 & 5.18124 \\
\hline & Kritik Değer & -8.10000 & -1.98000 & 0.23300 & 3.17000 \\
\hline & KY $_{\text {GSYiH }}$ & -2.12555 & -0.99952 & 0.47024 & 11.2405 \\
\hline & Kritik Değer & -8.10000 & -1.98000 & 0.23300 & 3.17000 \\
\hline & $\dot{\mathbf{I B S S}}_{\mathrm{GSYIH}}$ & -3.78500 & -1.37319 & 0.36280 & 6.47394 \\
\hline & Kritik Değer & -8.10000 & -1.98000 & 0.23300 & 3.17000 \\
\hline & 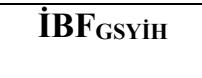 & -1.77143 & -0.84379 & 0.47633 & 12.4435 \\
\hline & Kritik Değer & -8.10000 & -1.98000 & 0.23300 & 3.17000 \\
\hline \multirow{9}{*}{$\begin{array}{c}\text { Birinci } \\
\text { Farklar }\end{array}$} & Değişken & $\mathbf{M Z}_{\mathbf{a}}$ & $\mathbf{M Z}_{\mathbf{t}}$ & MSB & MPT \\
\hline & ÖY $Y_{\text {GSYIH }}$ & $-13.3365 * *$ & $-2.58002 * *$ & 0.19346 & 1.84572 \\
\hline & Kritik Değer & -8.10000 & -1.98000 & 0.23300 & 3.17000 \\
\hline & KYGSYï & $-12.6507 * *$ & $-2.51501 * *$ & 0.19881 & 1.93668 \\
\hline & Kritik Değer & -8.10000 & -1.98000 & 0.23300 & 3.17000 \\
\hline & İBSGSYIH & $-12.9780 * *$ & $-2.53916^{* *}$ & 0.19565 & 1.91902 \\
\hline & Kritik Değer & -8.10000 & -1.98000 & 0.23300 & 3.17000 \\
\hline & İBF $_{\text {GSYIH }}$ & $-11.5657 * *$ & $-2.40476^{* *}$ & 0.20792 & 2.11833 \\
\hline & Kritik Değer & -8.10000 & -1.98000 & 0.23300 & 3.17000 \\
\hline
\end{tabular}

Yukarıda tablo 2'de yer alan (**) değerleri birinci farklara göre NG- birim kök testi sonuçları, çalışmada kullanılan değişkenlerin birinci farkları alındığında durağan olduklarını göstermektedir. \% 5 anlamlılık seviyesinde $M Z_{\mathrm{a}}$ ve $M Z_{\mathrm{t}}$ testleri için hesaplanan istatistik değerleri, $\mathrm{Ng}$ ve Perron (2001) tarafından hesaplanan kritik değerlerinden büyük olduğu için temel hipotez olan birim kökün varlığı hipotezi reddedilmektedir. MSB ve MPT testleri için hesaplanan istatistik değerleri ise, Ng ve Perron (2001) tarafindan hesaplanan kritik değerlerden küçük olduğu için temel hipotez olan birim kökün yokluğu hipotezi reddedilememektedir. 


\section{Y. KESBİÇ. - Ö. DÜNDAR - A. DEVRİM}

Değişkenler \% 5 anlamlılık seviyesinde birinci farkları alındığında durağan hale gelmektedir.

\subsection{Johansen Eşbütünleşme Testi Sonuçları}

Çalışmada Ng-Perron birim kök testi kullanılarak, serilerin durağanlığının sağlanması amacıyla farklarının alınması, serilerde bilgi kaybına neden olabilmekte, bu durum seriler arasındaki ilişkileri yok edebilmektedir. Söz konusu ilişkinin yok olup olmadığı Johansen eşbütünleşme analizi ile belirlenebilmektedir. Çünkü Johansen (1988) tarafından geliştirilen eş-bütünleşme analizi, seriler arasında durağan bir ilişki olması durumunda, söz konusu serilerin uzun dönemli denge ilişkisinin var olup olmadığının araştırılmasını mümkün kılmaktadır. Seriler arasında uzun dönem denge ilişkisinin var olması, bir diğer ifadeyle, serilerin eşbütünleşik olmaları, her bir serinin ortak bir stokastik trendin etkisi altında kaldığını göstermekte, bu durumda kurulan regresyon, sahte regresyon olmaktan ziyade, anlamlı bir regresyon olmaktadır.

Ng- Perron testi sonucunda serilerin birinci farkları alındığında durağan oldukları görülmüştür, böylece değişkenlerin eşbütünleşik olup olmadıklarının araştırılması mümkün olmuştur. Johansen eşbütünleşme testinin uygulanması sonucu ulaşılan sonuçlar, aşağıda tablo 3 ve tablo 4 'te görülmektedir.

Tablo 3. Kısıtlanmış Eş-Bütünleşme Derecesi Testi (İz)

\begin{tabular}{|l|c|c|c|l|}
\hline \multicolumn{5}{|c|}{ Unrestricted Cointegration Rank Test (Trace) } \\
\hline Ho Hipotezi & $\begin{array}{l}\text { Eigenvalue } \\
\text { (Özdeğer) }\end{array}$ & $\begin{array}{l}\text { Trace Statistic } \\
\text { (İz istatistiği) }\end{array}$ & $\begin{array}{l}\text { 0.05 Critical Value } \\
\text { (Kritik Değer) }\end{array}$ & $\begin{array}{l}\text { Prob. } \\
\text { (Olasılık) }\end{array}$ \\
\hline Hiç Yok * & 0.772654 & 63.69343 & 47.85613 & 0.0008 \\
\hline En Çok 1 Tane & 0.361591 & 23.69876 & 29.79707 & 0.2135 \\
\hline En Çok 2 Tane & 0.280568 & 11.58182 & 15.49471 & 0.1781 \\
\hline En Çok 3 Tane & 0.094858 & 2.690899 & 3.841466 & 0.1009 \\
\hline Sonuç & 1 eşbütünleşme vektörü vardır. \\
\hline
\end{tabular}


Dokuz Eylül Üniversitesi İktisadi ve İdari Bilimler Fakültesi Dergisi Cilt:31, Sayl:2, Yll:2016, ss. 59-94

Eşbütünleşme analizi doğrultusunda, \% 5 anlamlılık düzeyinde iz testi sonuçlarına göre, 1 adet koentegre vektörünün var olduğu, maksimum öz değer testi sonuçlarına göre de 1 adet koentegre vektörünün varlığı tespit edilmiştir. $\mathrm{Bu}$ durum, seriler arasında uzun dönemli bir ilişkinin varlığını mevcut kılmaktadır.

Tablo 4. Kısıtlanmamış Eş-Bütünleşme Derecesi Testi (Maksimum Özdeğer)

\begin{tabular}{|l|c|c|c|c|}
\hline \multicolumn{5}{|c|}{ Unrestricted Cointegration Rank Test (Maximum Eigenvalue) } \\
\hline & $\begin{array}{l}\text { Eigenvalue } \\
\text { (Özdeğer) }\end{array}$ & $\begin{array}{l}\text { Max-Eigen } \\
\text { Statistic(Özdeğer } \\
\text { İstatistiği) }\end{array}$ & $\begin{array}{l}\mathbf{0 . 0 5} \text { Critical } \\
\text { Value(Kritik } \\
\text { Değer) }\end{array}$ & $\begin{array}{l}\text { Prob. } \\
\text { (Olasılık) }\end{array}$ \\
\hline Hiç Yok & 0.772654 & 39.99467 & 27.58434 & 0.0008 \\
\hline En Çok 1 Tane * & 0.361591 & 12.11694 & 21.13162 & 0.5361 \\
\hline En Çok 2 Tane & 0.280568 & 8.890924 & 14.26460 & 0.2953 \\
\hline En Çok 3 Tane & 0.094858 & 2.690899 & 3.841466 & 0.1009 \\
\hline Sonuç & 1 eşbütünleşme vektörü vardır. & \\
\hline
\end{tabular}

\subsection{En Küçük Kareler Yöntemi (EKKY) Sonuçları}

Çalışmada aşağıda görülen denklem (28) kullanılarak, EKKY göre analiz gerçekleştirilmiştir. Denklem (28), kamu sabit sermaye yatırımlarının GSYİH’ye oranının $\left(K Y_{G S Y i H}\right)$, iç borç stokunun GSYİH'ye oranının $\left(I B_{G S Y i H}\right)$ ve iç borçlanma faiz oranının $(I B F)$, özel sabit sermaye yatırımlarının GSYIH'ye oranı (ÖO $\left.Y_{G S Y i H}\right)$ üzerindeki etkisini göstermektedir. Johansen eşbütünleşme sonuçlarına göre, seriler arasında uzun dönemli bir ilişkinin varlığı tespit edildikten sonra, EKKY ile değişkenler arasında ilişki kuran katsayılar tahmin edilmiş ve bu katsayıların ekonometrik olarak anlamlı olup olmadıkları belirlenmiştir.

$$
\ddot{O} Y_{G S Y i H}= \pm K Y_{G S Y i H}-I B S_{G S Y i H}-I B F
$$

İç borç stokundaki artış, kamunun kullandığı fonların artışı dolayısıyla özel sektörün erişebildiği kaynakların azaldığı anlamına gelmektedir. İç borç faiz 


\section{Y. KESBİÇ. - Ö. DÜNDAR - A. DEVRİM}

oranlarındaki artış ise, girişimciler için maliyetleri arttırdığından özel yatırımları azaltmaktadır.

Aşağıda denklem (29)'da verilen analiz sonuçlarına göre, Kamu sabit sermaye yatırımları özel sabit sermaye yatırımlarını dışlamaktadır. Kamu yatırımları, iç borç stoku ve iç borç faizi değişkenlerinin özel yatırımlar üzerindeki etkisi, negatif yönde olmaktadır. Kamu sabit sermaye yatırımlarında, iç borç stokunda ve iç borç faiz oranında görülen bir birimlik artış, özel sabit sermaye yatırımlarında sırasıyla $1.641885,-0.181155$ ve -0.025750 oranında bir azalıs oluşturmaktadır. Kamu sabit sermaye yatırımları, iç borç stoku ve iç borç faiz oranı değişkenlerine ait katsayılar, 0.05 düzeyinde istatistiksel olarak anlamlıdır. Model de, $\mathrm{F}$ istatistik değerinin 0.000466 olması nedeniyle anlamlıdır. Modelin açıklayıcı gücü $\left(\mathrm{R}^{2}\right)$, orta düzeydedir.

$$
\begin{aligned}
& \ddot{O} Y_{\text {GSYiH }}=-K Y_{\text {GSYiH }}-I B S_{\text {GSYiH }}-I B F \\
& \ddot{O} Y_{G S Y i H}=-1.641885 K Y_{G S Y i H}-0.181155 I B S_{G S Y i H}-0.025750 I B F \\
& \mathrm{R}^{2}=0,50 \mathrm{~F}(0,000466) .
\end{aligned}
$$

Tablo 5. EKKY Sonuçları

\begin{tabular}{|c|c|c|c|c|}
\hline Değişkenler & Katsayılar & $\begin{array}{c}\text { Standart } \\
\text { Sapma }\end{array}$ & $\begin{array}{c}\text { t İstatistik } \\
\text { Değerleri }\end{array}$ & $\begin{array}{c}\text { P Olasılık } \\
\text { Değerleri }\end{array}$ \\
\hline KY & -1.641885 & 0.382020 & -4.297902 & 0.0002 \\
\hline IBS & -0.181155 & 0.042457 & -4.266829 & 0.0002 \\
\hline IBF & -0.025750 & 0.009234 & -2.788763 & 0.0100 \\
\hline
\end{tabular}

\subsection{Engle Granger Nedensellik Testi Sonuçları}

Engle Granger Nedensellik Testine göre oluşturulan hipotezlere göre; $\mathrm{H}_{0}$ : Granger nedeni değildir. $\mathrm{H}_{1}$ : Granger nedenir. Aşağıda tablo 6'da Granger nedensellik testi sonuçları verilmektedir.

Test sonuçlarına göre; kamu yatırımları ile özel yatırımlar, iç borç stoku ile özel yatırımlar, iç borç faiz oranı ile özel yatırımlar, iç borç stoku ile kamu yatırımları 
Dokuz Eylül Üniversitesi İktisadi ve İdari Bilimler Fakültesi Dergisi Cilt:31, Sayl:2, Yll:2016, ss. 59-94

ve iç borç faiz oranı ile iç borç stoku arasında nedensellik ilişkisi bulunmamakta, her iki değişken birbirinin 0,05 anlamlllık seviyesinde granger nedenini oluşturmamakta ve her iki değişken birbirini etkilememektedir.

Tablo 6. Granger Nedensellik Testi Sonuçları

\begin{tabular}{|c|c|c|c|}
\hline Nedensellik Yönü & Obs & F-Statistic & Prob. \\
\hline $\mathrm{KY}_{\mathrm{GSYiH}} \Rightarrow \mathrm{Ö} \mathrm{Y}_{\mathrm{GSY}}$ & 27 & 0.39780 & 0.6765 \\
\hline ÖY ${ }_{\mathrm{GSYIH}} \Rightarrow \mathrm{K} Y_{\mathrm{GSYiH}}$ & & 1.13272 & 0.3402 \\
\hline $\mathrm{IBS}_{\mathrm{GSYiH}} \Rightarrow \quad \mathrm{ÖY}_{\mathrm{GSYIH}}$ & 27 & 0.32432 & 0.7264 \\
\hline ÖY ${ }_{\mathrm{GSYiH}} \Rightarrow \mathrm{IBS}_{\mathrm{GSYIH}}$ & & 0.12068 & 0.8869 \\
\hline IBF $\Rightarrow$ ÖY $_{\mathrm{GSYIH}}$ & 27 & 1.03133 & 0.3731 \\
\hline ÖY ${ }_{\mathrm{GSY}} \Rightarrow \mathrm{IBF}$ & & 1.80454 & 0.1881 \\
\hline $\mathrm{IBS}_{\mathrm{GSY}} \Rightarrow \mathrm{KY}_{\mathrm{GSY}} \mathrm{IH}$ & 27 & 2.74320 & 0.0864 \\
\hline $\mathrm{KY}_{\mathrm{GSYIH}} \Rightarrow \mathrm{IBS}_{\mathrm{GSYIH}}$ & & 0.50472 & 0.6105 \\
\hline $\mathrm{IBF} \Rightarrow \mathrm{KY}_{\mathrm{GSYIH}}$ & 27 & 0.22886 & 0.7973 \\
\hline $\mathrm{KY}_{\mathrm{GSYIH}} \Rightarrow \mathrm{IBF}$ & & 0.96329 & 0.3972 \\
\hline $\mathrm{IBF} \quad \Rightarrow \quad \mathrm{IBS}_{\mathrm{GSYIH}}$ & 27 & 8.36049 & 0.0020 \\
\hline $\mathrm{IBS}_{\mathrm{GSYiH}} \Rightarrow \mathrm{IBF}$ & & 4.16390 & 0.0293 \\
\hline
\end{tabular}

İç borç faiz oranı ile iç borç stoku arasında çift yönlü nedensellik ilişkisi bulunmakta, her iki değişken birbirinin 0,05 anlamlılık seviyesinde granger nedenini oluşturmakta ve her iki değişken birbirini etkilemektedir.

\section{SONUÇ}

Çalışmada kamu yatırımlarının borçlanma ile finanse edilmesinin dışlama etkisi yoluyla ekonomide yol açtı̆̆ etkiler konusunda; Klasik iktisat, Neo-klasik iktisat ve Monetarist iktisadın hemen hemen aynı yönde görüşe sahip olduğu, Keynesyen iktisadın ise, diğer iktisadi sistemlerden daha farklı bir görüşe sahip olduğu 


\section{Y. KESBİÇ. - Ö. DÜNDAR - A. DEVRİM}

belirlenmiştir. Keynesyen iktisada göre, kamu yatırım harcamalarındaki artışın meydana getireceği milli geliri arttırıcı etki, özel sektörün dışlanma etkisinden daha fazla oranda olmakta, bir başka ifadeyle kısmi bir dışlama etkisi oluşmakta, bu nedenle uygulanan genişletici maliye politikaları ekonomide olumlu bir etki oluşturmaktadır. Diğer iktisadi düşünce sistemlerinde söz konusu etki, olumsuz yönde olmaktadır.

Özetle, konuyla ilgili teorik analiz yapıldığında, dışlama etkisinin var olduğu konusunda iktisadi düşünce sistemlerine göre farklı görüşler olsa dahi, sonuç olarak dışlama etkisinin kısmen de olsa var olduğu görüşü, tüm iktisadi düşünce sistemleri tarafından savunulmuştur. Dışlama etkisi üzerine yapılan teorik tartışmaları, ampirik çalışmalar gecikmeli olarak izlemiştir. 1970'li yıllarda değişen ekonomik koşullar ile birlikte kamu kesiminin ekonomideki yerinin sorgulanmaya başlanmasıyla, ampirik çalışmalar yoğunluk kazanmıştır.

Dışlama etkisi ampirik olarak analiz edildiğinde; kamu yatırımlarının özel sektör yatırımları üzerinde dışlama etkisi oluşturup oluşturmadığı doğrultusunda görüş birliğine ulaşılmadığı görülmüştür. Türkiye ile ilgili yapılan çalışmaların çoğunluğunda ise, kamu yatırımlarının özel sektör yatırımlarını dışladığ 1 yönünde sonuca ulaşılsa da, kamu yatırımlarının özel sektör yatırımları üzerinde çekme etkisi oluşturduğu yönünde sonuca ulaşılan çalışmalar da mevcuttur.

Dünya'da konuyla ilgili yapılmış son çalışmalardan Birian, Chiwira, Chiranga ve Enowbi (2012), çalışmalarında kamu yatırımlarındaki kısa dönemli değişikliklerin özel sektör yatırımlarında tamamlayıcıllk etkisi oluşturduğu yönünde sonuca ulaşırken; Dianne ve Lee (2011), kamu yatırımlarının özel sektör yatırımlarını dışladığı yönünde sonuca ulaşmışlardır. Bu durum, Dünya'da konuyla ilgili en son yapılan çalışmalarda da önceki çalışmalar gibi görüş birliğine ulaşılmadığının bir göstergesi olabilir.

Türkiye için konuyla ilgili yapılan son çalışmalardan biri, Tülümce ve Buyrukoğlu'nun 2013 yılında yaptıkları çalışmadır. Tümlüce ve Buyrukoğlu (2013:61), gelişmekte olan ülkelerde yapılan çalışmalarda kamu yatırımları ve özel 
yatırımlar arasında genellikle tamamlayıcılık etkisi olduğu yönünde bulgulara ulaşıldığını, bu durumun beklentilerle aynı doğrultuda olduğunu öne sürmüşlerdir. $\mathrm{Bu}$ durumun nedeni olarak, gelişmekte olan ülkelerde kamu yatırımlarının özel sektörü teşvik etmede ve kalkınmanın sağlanmasında önemli bir faktör olduğu; kamu yatırımlarının özel sektör yatırımlarını kolaylaştırıcı olduğu gibi karlılığı da artırarak, sermaye birikimine katkıda bulunduğunu ifade etmişlerdir. Dünya'da yapılan ampirik çalışmalarda, gelişmekte olan ülkeler için genelde söz konusu yönde sonuçlara ulaşılmıştır. Ancak, gelişmekte olan bir ülke konumunda olan Türkiye'de yapılan ampirik çalışmalarda beklenilenin tersine, genellikle kamu yatırımları ve özel yatırımlar arasında dışlayıcı bir etkinin olduğu sonucuna ulaşılmıştır. Bu çalışmada söz konusu durumda bir değişikliğin olup olmadığg araştırılmak istenmiştir. 2013 yılından sonra Türkiye için konuyla ilgili çalışma yapıldığına pek rastlanılamamıştır. Bu nedenle bu çalışmada Türkiye'de 19862014 dönemi için dışlama etkisinin var olup olmadığı, genel olarak teoriyle ve Türkiye için yapılan çalışmaların çoğunda ulaşılan sonuçlarla aynı yönde bir sonucun elde edilip edilemeyeceği kapsamında, Johansen eşbütünleşme testi, EKKY ve Engle Granger nedensellik testi ile analiz edilmiştir.

Johansen eşbütünleşme testi ve EKKY sonuçlarına göre; kamu sabit sermaye yatırımlarının özel sektör sabit sermaye yatırımlarını dışladığı belirlenmiştir. İç borç faizi ve iç borç stokunun özel sektör yatırımlarını negatif yönde etkilediği görülmüsşür. Kamu sabit sermaye yatırımları, iç borç stoku ve iç borç faiz oranı değişkenlerine ait katsayılar, 0.05 düzeyinde istatistiksel olarak anlamlıdır. Model de, $\mathrm{F}$ istatistik değerinin 0.00466 olması nedeniyle anlamlıdır. Modelin açıklayıcı gücünün $\left(\mathrm{R}^{2}\right)$, orta düzeyde olduğu sonucuna ulaşılmıştır. Granger nedensellik testi sonuçlarına göre ise, kamu yatırımları ile özel yatırımlar, iç borç stoku ile özel yatırımlar, iç borç faiz oranı ile özel yatırımlar, iç borç stoku ile kamu yatırımları ve iç borç faiz oranı ile iç borç stoku arasında nedensellik ilişkisi bulunmamakta, her iki değişken birbirinin 0,05 anlamlılık seviyesinde granger nedenini oluşturmamakta ve her iki değişken birbirini etkilememektedir. İç borç faiz oranı ile iç borç stoku arasında çift yönlü nedensellik ilişkisi bulunmakta, her iki 


\section{Y. KESBİÇ. - Ö. DÜNDAR - A. DEVRİM}

değişken birbirinin 0,05 anlamlılık seviyesinde granger nedenini oluşturmakta ve her iki değişken birbirini etkilemektedir.

Çalışmada ulaşılan sonuçların, dışlama etkisi konusunda iktisadi sistemlerin teorik görüşlerinden Keynesyen görüşün yaklaşımını desteklemediği, diğer iktisadi görüşleri destekler nitelikte olduğu söylenebilmektedir. Söz konusu sonuçların, Türkiye için yapılan ampirik çalışmaların çoğunda ulaşılan sonuçlarla, aynı yönde olduğu görülmüsstür. Bu doğrultuda, Türkiye'de kamu yatırımlarının özel sektör yatırımlarını dışladığı söylenebilmektedir. Çalışmada Türkiye için dışlama etkisi olduğu yönünde bir sonuca ulaşılması nedeniyle, ileride gerçekleştireceğimiz çalışmada, dışlama etkisi söz konusu olsa dahi, büyümeye katkısı olan kamu yatırım harcama türlerinin var olup olmadığı, diğer bir deyişle, kamu yatırımlarının büyüme ile ilişkisinin belirlenmesi amaçlanmıştır. $\mathrm{Bu}$ çalışmanın, ileride ifade edilen yönde gerçekleştirilecek olan bir çalışmaya temel oluşturacağı düşünülmektedir.

Kamu yatırımları sonucu oluşan bütçe açıklarının finansmanında, iç borçlanmaya gidilmesi yerine, kayıt dışı ekonominin kayıt altına alınması sonucunda vergi gelirlerini arttırma yoluna gidilebilir. Kamunun, özel sektör ile rekabet halinde yatırımlar yerine, özel sektör üzerinde çekme etkisi yaratabilecek yatırımlar gerçekleştirmesi, kamu yatırımlarının özel sektör yatırımlarını dışlama etkisini azaltabileceği düşünülebilir. Bunların yanı sıra kamunun, özel sektör yatırımlarını artırmak için özel sektöre yönelik teşvikler sağlaması, özel sektör yatırımlarını arttırıcı etki yaratabilir.

\section{KAYNAKÇA}

AHMED, H. , MILLER, S. M. (2000), "Crowding-Out and Crowding-In Effects of the Components of Government Expenditure", Contemporary Economic Policy, $18(1), 124-133$.

ARGIMON, I. , GONZALEZ-PARAMO, J. M. , ROLDAN, J. M. (1997), "Evidence of Public Spending Crowding-out from a Panel of OECD Countries", Applied Economics, 29(8),1001-1010. 
ASCHAUER, D. A. (1988), "Government Spending and the Falling Rate of Profit”, Economic Perspectives, 6, 11-17.

ALTAY, O. , ALTIN, O. (2008), “Türkiye'de Kamu Harcamalarının Ekonomik Büyüme ve Yatırımlar Üzerine Etkilerinin Analizi (1980-2005)”, Ege Akademik Bakış, 8(1), 267-285.

ALTUNÖZ, U. (2013), "Kamu Kesimi İç Borçlanmasının Özel Yatırım Harcamaları Üzerinde Etkisi: Türkiye Örneği”, Uludağ Üniversitesi Iktisadi ve İdari Bilimler Fakültesi Dergisi, 32(2), 25-53.

BAHMANI-OSKOOEE, M. (1999), "Do Federal Budget Deficits Crowd Out or Crowd In Private Investment?", Journal of Policy Modeling, 21, 633-640.

BAŞAR, S. , TEMURLENK, S. M. (2007), "Investigating Crowding-Out Effect of Government Spending for Turkey: A Structural Var Approach", Atatürk Üniversitesi İktisadi ve İdari Bilimler Dergisi, 21(2), 95-104.

BERBER, M. (2003), “Türkiye'de Özel ve Kamu Yatırım Harcamaları - Ekonomik Büyüme İlişkisi Uzun Dönem Analizi”, İktisat, Işsletme ve Finans, 18(209), 58-70.

BIRIAN, M. , CHIWIRA, O. , CHIRANGA, N. , ENOWBI, B. M. (2012), "The Causal Relationship between Private and Public Investment in Zimbabwe", British Journal of Economics, Management \& Trade, 2(3), 239-264.

BLEJER, M.I. , KHAN, M. S.(1984), "Government Policy and Private Investment in Developing Countries", Staff Papers - International Monetary Fund, 31(2), 379403.

BURNEY, N. A. , YASMEEN, A. (1989), "Government Budget Deficits and Interest Rates: An Empirical Analysis for Pakistan", The Pakistan Development Review, 28(4), 971-980.

CARLSON, K. M. , SPENCER, R. W.(1975), "Crowding Out and its Critics", Federal Reserve Bank of St. Louis, 2-17.

CASHIN, P. (1995), "Government Spending, Taxes, and Economic Growth”, IMF Staff Papers, 42(2), 237-269.

DIANNE, A. , LEE, C. G. (2011), "Dynamic Interactions between Public Investment, Private Domestic Investment and Foreign Direct Investment: Evidence from Indonesia", International Research Journal of Finance and Economics, 77, 2011, 67-73.

EASTERLY, W. (1989), "Policy Distortions, Size of Government and Growth", NBER Working Paper, No. 3214, 1-44. 


\section{Y. KESBİÇ. - Ö. DÜNDAR - A. DEVRİM}

ERDEN, L. (2005), "Public and Private Investment in a Vector Error Correction Model: Empirical Evidence from Turkey", Hacettepe Üniversitesi İktisadi ve İdari Bilimler Dergisi, 23(1), 17-27.

ERTAN, G. (2004), "Crowding Out Mechanism Ongoing in Turkey", Yayınlanmamış Yüksek Lisans Tezi.

FRIEDMAN, M. (1966), "Interest Rates and the Demand for Money", Journal of Law and Economics, 9, 71-85.

FRIEDMAN, M. (1972), "Comments on the Critics", Journal of Political Economy, 80(5), 906-950.

FLOYD, J. E. , HYNES, A. J. (1978), "Deficit Finance and 'First-Round' Crowding out: A Clarification", The Canadian Journal of Economics / Revue canadienne d'Economique, 11(1), 97-105.

GUJARATI, D. , N. (2003), Basic Econometrics, McGraw-Hill Higher Education, USA.

HASSAN, S. , OTHMAN, Z. , KARIM, M. Z. A. (2011), "Private and Public Investment in Malaysia: A Panel Time-Series Analysis", International Journal of Economics and Financial Issues, (1)4, 199-210.

HATANO, T. , (2010), "Crowding-in Effect of Public Investment on Private Investment", Public Policy Review, 6(1), Policy Research Institute, Ministry of Finance Japan, 105-120.

HYDER, K. (2001), "Crowding-out Hypothesis in a Vector Error Correction Framework: A Case Study of Pakistan", The Pakistan Development Review, 40(4), 633-650.

JOHANSEN, S. (1988), "Statistical Analysis of Cointegration Vectors", Journal of Economic Dynamics and Control, 12(2-3), 231-254.

JORGENSON, D. W. (1971), "Econometric Studies of Investment Behavior: A Survey", Journal of Economic Literature, 9(4), 1111-1147.

KAR, M. , TABAN, S. (2003), "Kamu Harcama Çeşitlerinin Ekonomik Büyüme Üzerine Etkileri”, Ankara Üniversitesi SBF Dergisi, 58(3), 145-169.

KESBİÇ, C. Y. (1998), “1980 Sonrası Dönemde Kamu Kesiminin Özel Kesimi Dışlama Etkisi: Bir Model Analizi”, Dokuz Eylül Üniversitesi İktisadi ve İdari Bilimler Fakültesi Dergisi, 13(2), 147-161. 
KHAN, A. H. (1988), "Macroeconomic Policy and Private Investment in Pakistan", The Pakistan Development Review, 27(3), 277-291.

KHAN, M. S. , REINHART, C. M. (1989), "Private Investment and Economic Growth in Developing Countries", IMF Working Paper 0440, 1-15.

KUŞTEPELİ, Y. (2005), "Effectiveness of Fiscal Spending: Crowding Out and/or Crowding In?”, Yönetim ve Ekonomi,12(1), 185-192.

LOONEY, R. E. (1995), "Public Sector Deficits and Private Investment: A Test of the Crowding-out Hypothesis in Pakistan's Manufacturing Industry", The Pakistan Development Review, 34(3), 277-297.

MITRA, P. (2006), "Has Government Investment Crowded out Private Investment in India?", The American Economic Review, 96(2), 337-341.

NAQVI, N. H. (2002), "Crowding-in or Crowding-out? Modelling the Relationship between Public and Private Fixed Capital Formation Using Co-integration Analysis: The Case of Pakistan 1964-2000", The Pakistan Development Review, 41(3), 255-275.

NAQVI, N. H. , TSOUKIS, C. (2003), "Does Public Investment Crowd Out Private Investment? Evidence on Investment and Growth in Asia, 1971-2000", European Research Studies, 6(1-2), 58-72.

NAZMI, N. , RAMIREZ, M. D. (1997), "Public and Private Investment and Economic Growth in Mexico", Contemporary Economic Policy, 15, 65-75.

OSHIKOYA, T. W. (1994), "Macroeconomic Determinants of Domestic Private Investment in Africa: An Empirical Analysis", Economic Development and Cultural Change, 42(3), 573-596.

ÖZKER, N. (2003), "Dışlama (Crowding-Out) Etkisi Açısından Kamu Harcamaları Politikası ve Türkiye Örnekleminde Ekonomik Büyüme İlişkisi", Atatürk Üniversitesi İktisadi ve İdari Bilimler Fakülte Dergisi, 17(3-4), 95-114.

RAMIREZ, M. D. (1994), "Public and Private Investment in Mexico, 1950-90: An Empirical Analysis", Southern Economic Journal, 61(1), 1-17.

SAEED, N. , BUKHARİ, S. K. H. , ALİ, A. , AHMAD, E. (2006), "The Impact of Public Investment on Private Investment: A Disaggregated Analysis", The Pakistan Development Review, 45(4), 639-663.

SERVEN, L. (1996), "Does Public Capital Crowd Out Private Capital? Evidence from India", The World Bank Policy Research, Working Paper 1613, 1-36. 


\section{Y. KESBİÇ. - Ö. DÜNDAR - A. DEVRİM}

SEVÜKTEKİN, M. , NARGELEÇEKENLER, M. (2007), Ekonometrik Zaman Serileri Analizi, Nobel Yayınları, İkinci baskı, Ankara.

SOLOW, R. M. (1956), "A Contribution to the Theory of Economic Growth", The Quarterly Journal of Economics, 70(1), 65-94.

SPENCER, R. W. , YOHE, W. P. (1970), "The 'Crowding Out' of Private Expenditures by Fiscal Policy Actions", Federal Reserve Bank of St. Louis Review, 12-24.

SUNDARARAJAN, V. , THAKUR, S. (1980), "Public Investment, Crowding out, and Growth: A Dynamic Model Applied to India and Korea", Staff Papers International Monetary Fund, 27(4), 814-855.

ŞIMŞEK, M. (2003), "Kamu Harcamalarının Özel Yatırımlara Etkileri, 19702001”, Cumhuriyet Üniversitesi İktisadi ve İdari Bilimler Dergisi, 4(2), 1-20.

TÜLÜMCE, S. Y. , BUYRUKOĞLU, S. (2013), "Türkiye'de Kamu ve Özel Yatırımlar Arasındaki İlişsinin Ampirik Analizi: Dışlama Etkisi (1980-2010)", Mali Çözüm, 59-77.

UYSAL, D. , MUCUK, M. (2003), "Crowding-Out (Dışlama) Etkisi: Türkiye Örneği (1975-2000)”, S.Ü. İ̈BF Sosyal ve Ekonomik Araştırmalar Dergisi, 1(5), 159-171.

WAI, T. U. , WONG, C. (1982), "Determinants of Private Investment in Developing Countries", The Journal of Development Studies, 19(1), 19-36.

YAVUZ, N. Ç. (2001), “Türkiye'de Kamu Yatırım Harcamalarının Özel Sektör Yatırım Harcamalarını Dışlama Etkisi Üzerine Ekonometrik Bir Analiz (1990-1 / 2000-IV)", Kamu-Iş, 6(2), 47-64.

YAVUZ, N. (2005), "Türkiye'de Kamu Harcamalarının Özel Sektör Yatırım Harcamalarını Dışlama Etkisinin Testi (1980-2003)", Marmara Üniversitesi Iktisadi ve İdari Bilimler Fakültesi Dergisi, 20(1), 269-284. 